\title{
Summertime Surface Mass Balance and Energy Balance of Urumqi Glacier No. 1, Chinese Tien Shan, Modeled by Linking COSIMA and in-Situ Measured Meteorological Records
}

\section{Hongliang Li}

Chinese Academy of Sciences

Puyu Wang ( $\nabla$ wangpuyu@lzb.ac.cn )

Chinese Academy of Sciences

\section{Zhongqin Li}

Chinese Academy of Sciences

\section{Shuang Jin}

Chinese Academy of Sciences

Jie He

Chinese Academy of Sciences

\section{Research Article}

Keywords: ablation period, energy balance, mass balance, sensitivity analysis, Urumqi Glacier No. 1, Tien Shan

Posted Date: November 1st, 2021

DOl: https://doi.org/10.21203/rs.3.rs-1010764/v1

License: @ (i) This work is licensed under a Creative Commons Attribution 4.0 International License. Read Full License 


\section{Abstract}

To get a better overview of atmosphere-driven mass changes at Urumqi Glacier No.1, Chinese Tien Shan, the surface energy balance and mass balance is modeled by linking the COupled Snowpack and Ice surface energy and MAss balance model (COSIMA) with in-situ measured meteorological record for the ablation period 2018. After a manual model optimization, the model produces realistic results compared to in-situ measured surface temperature, snow height and seasonal mass balance. Our results reveal that Urumqi Glacier No.1 experienced a significant mass loss, with an average value of $-0.77 \mathrm{~m}$ w.e. over the ablation period 2018. The main components in energy balance were radiation components $\left(S W_{\text {net }}\right.$ and $\left.L W_{\text {net }}\right)$ and turbulent fluxes. Surface melt and solid precipitation were dominated components of mass balance. The COSIMA can reproduce the glaciological mass balance compared with other models. Sensitivity analysis showed that the mass balance was more sensitive to the temperature than precipitation, and mass loss caused by temperature increase of $1 \mathrm{~K}$ needed to be compensated by at least $40 \%$ precipitation increase. Air temperature during the ablation period was more important than annual precipitation in controlling mass balance changes on Urumqi Glacier No.1. These findings will enhance our understanding of the mechanisms underlying mass balance processes of ablation period and their contribution to the acceleration of glacier retreat in Tien Shan.

\section{Introduction}

The glaciers in the Tien Shan provide the sources of rivers that supply water to billions of people (Farinotti et al., 2015). Several studies have found the glaciers in Tien Shan represented an accelerated melting tendency recently (Wang et al., 2019). The majority of glaciers have been receding and shrinking (Yao et al., 2012), which could endanger the water resource in the downstream region (Immerzeel et al., 2010).

Given the importance of glaciers in the Tien Shan, the quantitative understanding of the physical relationship between glaciers and climate is necessary to help predicting the responses of glaciers to climatic change and its potential impacts. Most previous studies on the response of glacier mass balance to climate change in the Tien Shan have focused on the effect of annual air temperature change (Farinotti et al., 2015; Pieczonka et al., 2015; Sakai and Fujita, 2017; Wang et al., 2017, 2016). However, the air temperature in the Tien Shan shows large spatial discrepancy in seasonal variations (Wang et al., 2020). Few studies on the Tien Shan quantify the effects of seasonal air temperature changes on changes in glacier mass balance. Furthermore, glaciers in the western and eastern Tien Shan exhibit strong heterogeneity changes due to their different climatic settings (Wang et al., 2015). Due to the lack of in-situ glacio-meteorological observations in different regions of the Tien Shan, this limits our understanding of the relationship between glaciers and climate change. Their relationship can be resolved by studying glacier energy and mass balance, which has been conducted in detail on many mountain glaciers and ice sheets around the world (Bintanja et al., 1997; Oerlemans and Klok, 2002; Kaser et al., 2004). A large number of studies about glacier energy and mass balance have been carried out on the Tibetan Plateau glaciers (Fujita and Ageta, 2000; Yang et al., 2011; Mölg et al., 2012; Huintjes et al., 2015a, b; Sun et al., 2018; Li et al., 2018; Zhu et al., 2020), yet few systematic studies have been conducted on Tien Shan glaciers (Kang et al., 1992; Han et al., 2005). 
Compared with the previous studies in the Urumqi Glacier No.1, hourly high-resolution surface mass balance modeling was only available until 2012 (Che et al., 2019; Li, 2020), but the parameterizations of subsurface energy and mass fluxes were not incorporated or poorly resolved by these commonly models. Huintjes et al. $(2015 a, b)$ has applied COupled Snowpack and Ice surface energy and MAss balance model (COSIMA) with observations from Automatic Weather Station (AWS) or High Asia Refined (HAR) reanalysis data as atmospheric input to investigate glacier-wide surface energy balance and mass balance processes. Subsurface processes can be well resolved by COSIMA. In general, parameterization scheme within COSIMA makes the calculation of mass balance more reasonable. However, as yet, COSIMA has not been tested in the Tien Shan using hourly AWS observation data as input.

Taking this into account, COSIMA was applied to the Urumqi Glacier No. 1, Chinese Tien Shan, forcing by hourly meteorological data collected at an AWS on the glacier surface. We calculated the energy fluxes and mass balance at the glacier surface and in the subsurface layers and conducted a comparison with different types of field in-situ measurements to validate model performance. From our model results we wanted to emphasize the discussion of parametrization of the surface energy fluxes and their ability to reproduce the mass balance. The sensitivity test was also carried out and the atmospheric variables controls on mass balance are identified over the study period.

\section{Study Site}

Urumqi Glacier No.1 $\left(43^{\circ} 06^{\prime} \mathrm{N}, 86^{\circ} 49^{\prime} \mathrm{E}\right)$ is a typical continental, valley-type glacier, covering an area of 1.52 $\mathrm{km}^{2}$ (Li et al., 2021). It consists of two independent small glaciers: the east branch (EB) and the west branch (WB), and its altitude ranges between 3743 to $4267 \mathrm{~m}$ m.s.I. Urumqi Glacier No.1 is situated on the northern slope of Tianger Summit II in the eastern Tien Shan (Fig. 1). It is situated in the continental climate zone. Summer months at Urumqi Glacier No.1 are dominated by westerly circulation causing a cold climate with little precipitation. However, annual precipitation is $460 \mathrm{~mm}$, and around $87 \%$ of the annual total falls between May and September (Jia et al., 2019). According to Liu et al. (1997), this glacier is therefore a typical summeraccumulation-type glacier because both accumulation and ablation take place simultaneously between June and September.

\section{Model Description}

\subsection{COSIMA structure}

COSIMA is a physical surface energy and mass balance model that assumes mass conservation in the snowpack. Thus, COSIMA couples a surface energy balance to a multi-level subsurface model, and it can calculate energy and mass balance for different components, including energy balance, meltwater percolation, refreezing and densification (Huintjes et al., 2015a). Now, COSIMA is available online as an opensource software and used for this study (https://bitbucket.org/glaciermodel/cosima; last accessed on 17 June 2021; Huintjes et al., 2015a). It is in detail presented by Huintjes et al. (2015a, b) and Wang et al. (2020). COSIMA calculates the mass balance of the surface melt, solid precipitation, sublimation, deposition, and subsurface melt at hourly time step. The surface energy balance equation governs the calculation of the mass fluxes: 
$F=S W_{\text {in }}(1-a)+L W_{\text {in }}+L W_{\text {out }}+Q_{\text {sens }}+Q_{\text {lat }}+Q_{G} \cdots$

Where $S W_{\text {in }}, L W_{\text {in }}$ and $L W_{\text {out }}$ represents incoming shortwave radiation, incoming longwave radiation and outgoing longwave radiation, respectively. $a$ is the surface albedo. $Q_{\text {sens }}$ and $Q_{\mathrm{lat}}$ are turbulent sensible and latent heat flux, respectively. $Q_{\mathrm{G}}$ is the ground heat flux which consists of fluxes of heat conduction $\left(Q_{\mathrm{C}}\right)$ and penetrating shortwave radiation $\left(Q_{\mathrm{PS}}\right) . Q_{P S}$ is always negative because it transfers energy from the glacier surface into the snow or ice. The heat flux from liquid precipitation is neglected within COSIMA according to Huintjes et al. $(2015 a, b)$. The flux towards the surface is considered positive, while the flux from the surface has a negative sign. Only sublimation causes mass loss when the surface temperature is below $273.16 \mathrm{~K}$. If surface temperature exceeds the melting point, it is set to $273.16 \mathrm{~K}$, and the excess energy is converted into the heat flux for snow/ice melting (Huintjes et al., 2015a).

The double critical temperature index method is used to separate solid and liquid precipitation in COSIMA. It is liquid precipitation when the air temperature is higher than $6{ }^{\circ} \mathrm{C}$, whilst it is solid precipitation when lower than $0{ }^{\circ} \mathrm{C}$ in our study region. The air temperature between the two critical air temperatures is calculated by linear interpolation (Jia et al., 2020). In COSIMA, the albedo is calculated using the parameterization of Oerlemans and Knap (1998). The ice albedo variation in the Urumqi Glacier No.1 has a range of $0.06 \sim 0.44$ due to due to topographic effects and light-absorbing impurities (Yue et al., 2017). Manual tests and inspection of albedo in Landsat-8 data showed that the albedo decreased from a fresh snow of 0.83 to a firn albedo of 0.58 , with an aging factor of 1.1 day after the snowfall events. The albedo drops to 0.35 when glacier surface is without snow layer (Yue et al., 2017). The depth scaling factor of the albedo is $3 \mathrm{~cm}$ after manual tests (Table 2). The vertical profiles of subsurface temperature and density are key for $Q_{G}$. The subsurface temperature is solved by the thermodynamic thermal equation (Anderson, 1976). And subsurface density is calculated through an empirical relation following Herron and Langway (1980). The initial temperature profile is defined by the available subsurface measurements and linear interpolation with depth. The initial snow density profile is calculated from a linear interpolation between $250 \mathrm{~kg} \mathrm{~m}^{-3}$ of the uppermost snow layer and $550 \mathrm{~kg} \mathrm{~m}^{-3}$ from the bottom snow layer.

The distributed $S W_{\text {in }}$ including effects from both terrain shading and cloud cover were calculated based on the radiation model in COSIMA and the detailed information about the parameters are given in Kumar et al. (1997). $L W_{\text {in }}$ and $L W_{\text {out }}$ are obtained by the Stefan-Boltzmann law. For $L W_{\text {in, }}$ atmospheric emission rates $\varepsilon$ is calculated using Klok and Oerlemans (2002). To calculate the turbulent heat fluxes, COSIMA assumes that the surface roughness length varies with the duration of the fresh snow to firn snow (Molg et al. 2009). Surface roughness length ranged from a fresh snow value of $0.24 \mathrm{~mm}$ (Gromke et al., 2011) increases linearly to a firn snow value of $4 \mathrm{~mm}$ (Brock et al., 2006). If the glacier surface is without snow, the bare ice is assumed to be $1.7 \mathrm{~mm}$ (Cullen et al., 2007). The correction of turbulent fluxes under stable conditions is based on the Richardson number (Braithwaite,1995). The $Q_{\mathrm{C}}$ is determined by the temperature difference between the surface layer and the two top subsurface layers, depending on the thermal conductivity of the medium (ice or snow). The thermal conductivity is calculated from the subsurface density $\left(\rho\right.$, in $\mathrm{kg} \mathrm{m}^{-3}$ ) (Anderson, 1976). The $Q_{\mathrm{PS}}$ is calculated according to Bintanja and van den Broeke (1995). At the top level of the model, the proportion of $S W_{\text {net }}$ absorbed in surface layer reaches an exponentially decreasing flux to the bottom layer 
and increases the subsurface temperature. For the fraction of the $S W_{\text {net }}$ absorption and extinction coefficients, we take the values of 0.8 and 2.5 for ice, and 0.9 and 17.1 for snow, respectively, as determined by Bintanja and van den Broeke (1995).

\subsection{COSIMA configuration}

The final COSIMA run was initiated on 00:00 a.m. 1 May 2018. The analyzed COSIMA output also started from this time. At this time there is a little fresh snow observed at the glacier surface facilitating the initialization process of the model. The input meteorological series of hourly air temperature, relative humidity, precipitation and incoming shortwave radiation were used for the timespan between 00:00 a.m. 1 May and 00:00 a.m. 31 August 2018. The input meteorological data and their processing were shown in section 4 . For the COSIMA modeling, the bottom temperature was $266.15 \mathrm{~K}$ as mean value for the ablation period at the AWS1. Therefore, the surface energy balance and mass balance from AWS1 is conducted for hourly values.

\subsection{Mass balance change assessment controlled by climatic factors}

To quantitatively assess whether ablation period air temperature or annual precipitation is more important for controlling the change in mass balance, a method was used in this study by analyzing interannual variability of ablation period air temperature $\left(\sigma_{T}\right)$ and annual precipitation $\left(C_{V}\right)$, respectively. This method has been successfully applied to the Chhota Shigri glacier in the western Himalayas, Parlung Glacier No. 94 in the southeast Tibetan Plateau, Muji Glacier in the northeastern Pamir by Azam et al. (2014), Yang et al. (2013), and $\mathrm{Li}$ et al. (2020). $\sigma_{T}$ refers to the standard deviation of air temperature during ablation period, $C_{V}$ is the ratio of the standard deviation to the annual precipitation. $\sigma_{T}$ or $C_{V}$ has been used to indicate interannual changes in ablation period air temperature and annual precipitation, respectively. Then COSIMA was run by virtue of modifying air temperature or precipitation to obtain respective mass balance change. In this study, the forcing data includes the ablation period air temperature and annual precipitation of Daxigou meteorological station and the detailed information has been described in section 4.1.

\section{Data Sources And Processing}

\subsection{Input meteorological data}

On 29 April 2018, AWS1 was installed on the glacier surface at an elevation of $4025 \mathrm{~m}$ a.s.l., which provided hourly meteorological variables (Fig. 1a, c, d). AWS2 was installed on the glacier terminal moraine in 2011 at an altitude of $3,835 \mathrm{~m}$ a.s.I. providing the same meteorological datasets as AWS1 and stored in the Campbell CR1000 data logger as 30-min mean values. Table1 shows the technical specifications of all sensors in AWS1 and AWS2. Detailed information of both AWSs can be found in Wang et al. (2020). The air temperature ( $T)$, relative humidity $(R H)$, precipitation $\left(P_{r}\right)$ and incoming shortwave radiation $\left(S W_{\text {in }}\right)$ recorded by AWS1 and AWS2, are required for this study. Unfortunately, due to harsh environmental conditions, there was a data gap spanning from 12:00 p.m. 20 August to 12:00 p.m. 22 August 2018. The following part will offer the process for filling in data gap. The annual precipitation and the mean air temperature in the ablation period of the

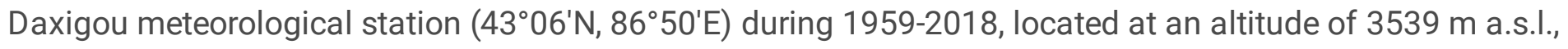
were used to assess how climate factors control the change in mass balance. 
Table 1. Information and parameters of AWSs sensor and precipitation gauge used in this study

\begin{tabular}{|c|c|c|c|c|c|}
\hline Instrument & Sensors & Company & Parameter* & Accuracy & Height \\
\hline \multirow[t]{6}{*}{ AWS1; AWS2 } & \multirow[t]{2}{*}{$\mathrm{HC} 2-\mathrm{S} 3$} & \multirow[t]{2}{*}{ Rotronic } & $T\left({ }^{\circ} \mathrm{C}\right)$ & $\pm 0.1^{\circ} \mathrm{C}\left(23^{\circ} \mathrm{C}\right)$ & $2 \mathrm{~m}$ \\
\hline & & & $R H(\%)$ & $\pm 0.8 \%\left(23^{\circ} \mathrm{C}\right)$ & $2 \mathrm{~m}$ \\
\hline & $\begin{array}{l}\text { Young } \\
05103\end{array}$ & RMYoung & $u\left(\mathrm{~m} \mathrm{~s}^{-1}\right)$ & $\pm 0.3 \mathrm{~m} \mathrm{~s}^{-1}$ & $2 \mathrm{~m}$ \\
\hline & PTB110 & Campbell & $\mathrm{P}(\mathrm{hPa})$ & $\pm 0.3 \mathrm{hPa}\left(20^{\circ} \mathrm{C}\right)$ & $2 \mathrm{~m}$ \\
\hline & \multirow[t]{2}{*}{ CNR4 } & \multirow[t]{2}{*}{ Kipp\&Zonen } & $\begin{array}{l}S W_{\text {in }} \text { and } S W_{\text {out }} \\
\left(\mathrm{W} \mathrm{m}^{-2}\right)\end{array}$ & $\pm 10 \%$ & \multirow[t]{2}{*}{$1.5 \mathrm{~m}$} \\
\hline & & & $\begin{array}{l}L W_{\text {in }} \text { and } L W_{\text {out }}(\mathrm{W} \\
\left.\mathrm{m}^{-2}\right)\end{array}$ & $\begin{array}{l}\left(\mathrm{T}:-40^{\circ} \mathrm{C} \sim 80^{\circ} \mathrm{C} ; \mathrm{RH}:\right. \\
0 \% \sim 100 \%)\end{array}$ & \\
\hline $\begin{array}{l}\text { Precipitation } \\
\text { gauge } \\
\text { (AWS1; AWS2) }\end{array}$ & $\mathrm{T}-200 \mathrm{~B}$ & Geonor & $P_{r}(\mathrm{~mm})$ & $\begin{array}{l} \pm 0.1 \mathrm{~mm} \\
\left(-40^{\circ} \mathrm{C} \sim 60^{\circ} \mathrm{C}\right)\end{array}$ & $1.7 \mathrm{~m}$ \\
\hline
\end{tabular}

* $T=$ air temperature; $P_{r}=$ precipitation; $P=$ air pressure; $R H=$ relative humidity; $u=$ wind speed; $S W_{i n}$ and $S W_{\text {out }}=$ incoming and outgoing shortwave radiation; $L W_{\text {in }}$ and $L W_{\text {out }}=$ incoming and outgoing longwave radiation; $T_{s}=$ surface temperature.

Due to frequent snowfall events, the top of the radiation sensor often forms snow and frost, which may affect $S W_{\text {in }}$ measurements, causing defects in the data. Correction for $S W_{\text {in }}$ must be carried out and the method was proposed by Van den broke et al. (2004). Since the $S W_{\text {in }}$ correlation coefficients of AWS1 and AWS2 reached 0.95 , the gap in the $S W_{\text {in }}$ was filled by establishing the linear regression between AWS1 and AWS2.

Both forms of rain and snow were recorded using a Geonor T-200B weighing bucket precipitation gauge. Considering the impact of wind speed on solid precipitation, the raw precipitation data was corrected by He et al. (2009). To prepare the continuous precipitation for the 2018 ablation period, the precipitation recorded by AWS1 and AWS2 were used to fill the data gap and obtain a vertical gradient of precipitation. And the air temperature data gap has also been filled by lapse rate for air temperature. The vertical gradient of precipitation and the lapse rate of air temperature were $1.6 \mathrm{~mm}(100 \mathrm{~m})^{-1}$ and $-1.1^{\circ} \mathrm{C}(100 \mathrm{~m})^{-1}$, respectively. Cloud cover $(M)$ was also a forcing variable, but not directly observed. Estimations were performed using the method described in Favier et al. (2004).

Hock et al. (2005) found that the wind speed depends on the meteorological station location, and it is impossible to get a general scheme to quantitatively analyze the wind speed on the glacier. Linear regression analysis of wind speed from AWS1 and AWS2 yielded hourly regression parameters that could then be used to reconstruct wind speed during ablation period at the AWS1. This method was previously applied by Yang et al. (2016). Contamination of relative humidity is also based on methods described by Hock et al. (2005), and it 
pointed out that the relative humidity varies relatively little between meteorological stations. The relative humidity at the AWS1 during ablation period was also reconstructed using the same method, so that it can be extended to the overall glacier surface. Moreover, the isothermal atmospheric pressure formula was used to obtain continuous air pressure (Zhou et al., 1997). Anyway, the gap time is just a short period and the effect on modeled results adopted by the methods mentioned above is limited.

\subsection{Topography and glacier mask}

The UAV survey (MATRICE 200) made by DJI Technology Co, Ltd. on 28 August 2018 has conducted on the Urumqi Glacier No. 1. Two flights were carried out with the flying height of $120 \mathrm{~m}$ for each flight. The overlap of each flight was $80 \%$, and the camera pitch angle was $70^{\circ}$. However, this survey failed to reach the entire glacier due to the lack of battery power caused by the low temperature. Finally the UAV-DEM was generated with a spatial resolution of $0.36 \mathrm{~m}$ based on Pix4D Mapper software and then resampled combined with Advanced Spaceborne Thermal Emission and Reflection Radiometer (ASTER) Global Digital Elevation Model Version 3 (GDEM 003) with a spatial resolution of $30 \mathrm{~m}$ obtained from National Aeronautics and Space Administration (NASA) Land Processes Distributed Active Archive Center (LPDAAC, http://www.usgs.gov) for acquiring glacier topography and digitizing glacier boundary.

\subsection{Glacier mass balance measurements for model evaluation}

Glacier mass balance of the Urumqi Glacier No. 1 was measured following the glaciological method using ablation stakes or snow pits. Thirty-six stakes were evenly distributed on the glacier at different elevation bands by a steam drill (Fig. 1a). The ablation stakes were measured at 29 April 2018 and 1 September 2018, respectively. The measurement items include the vertical height of stakes above the glacier surface, superimposed ice thickness and the density and thickness of each snow/firn layer at an individual ablation stake. Then all the measurement items were converted to water equivalent (w.e.) using the single-point density values from in-situ measurements. The summer mass balance at each stake were then calculated based on these data. Point values were calculated for individual elevation intervals. The mean specific mass balance, expressed as a function of elevation, was calculated by the interpolation and extrapolation of the point results to the whole glacier surface in order to compare with modeled mass balance.

\section{Results}

\subsection{Microclimatic conditions during ablation period}

The daily mean air temperature was approximately $-3.2{ }^{\circ} \mathrm{C}$ throughout the ablation period 2018 . Daily mean air temperature fluctuated dramatically for the first few days of ablation period (1 May-8 June) and stayed comparatively low. The daily mean air temperature almost remained above the melting point between 9 June and 28 August (Fig. 2a). The daily mean relative humidity and air temperature exhibited similar variations. Daily mean relative humidity was about $69 \%$ during ablation period indicating a fairly humid condition (Fig. 2b). Daily mean relative humidity in May was relatively low. High moisture was particularly evident in the mature period of the rainy season (June to August). The daily mean wind speed typically fell between $0.6 \mathrm{~m}$ $\mathrm{s}^{-1}$ and $5.3 \mathrm{~m} \mathrm{~s}^{-1}$, with an average of $2.3 \mathrm{~m} \mathrm{~s}^{-1}$ (Fig. 2c). Relatively high wind speed occurred before 27 June 
and then it became lower. The pressure during the ablation period was relatively stable, with an average of $625 \mathrm{hPa}$ (Fig. 2d). Moreover, the cloud cover declined until 22 May and then increased (Fig. 2e). The total precipitation during our observation period was approximately $692 \mathrm{~mm}$, and mostly occurred from June to August (Fig. 2f).

\subsection{Model optimization and evaluation}

COSIMA needs to carefully select parameter settings to produce optimal model performance. Since the modeling period is ablation period 2018, a manual trial and error method outperforms an automated Monte Carlo method for long-term documented modeled mass balance (Mölg et al., 2012; Cullen et al., 2014). A manual testing of parameter tuning provides a better understanding of the modeling results in response to configuration changes. A list of parameterization options available in COSIMA is presented in Table 5 in Appendix A. The range of values tested and optimized values for COSIMA run is shown in Table 2. Input data used from the two AWSs are from 00:00 a.m. 1 May to 00:00 a.m. 31 August for optimization. In the next step, the model is applied to Urumqi Glacier No.1 and the results are also evaluated (Section 3.4.3).

Table 2

List of key parameters, the range of values tested and optimized values for COSIMA run.

\begin{tabular}{|c|c|c|c|c|c|}
\hline Parameters & $\begin{array}{l}\text { Lower } \\
\text { bound }\end{array}$ & $\begin{array}{l}\text { Upper } \\
\text { bound }\end{array}$ & $\begin{array}{l}\text { Optimized } \\
\text { values }\end{array}$ & Unit & References \\
\hline Albedo fresh snow & 0.82 & 0.88 & 0.83 & - & $\begin{array}{l}\text { Measurement; Mölg et al. } \\
\text { (2012) }\end{array}$ \\
\hline Albedo firn snow & 0.5 & 0.6 & 0.58 & - & $\begin{array}{l}\text { Measurement; Mölg et al. } \\
\text { (2012) }\end{array}$ \\
\hline Albedo ice & 0.2 & 0.4 & 0.35 & - & $\begin{array}{l}\text { Measurement; Mölg et al. } \\
\text { (2012) }\end{array}$ \\
\hline Albedo time scale & 1 & 3 & 1.1 & day & $\begin{array}{l}\text { Measurement; Mölg et al. } \\
(2012)\end{array}$ \\
\hline Albedo depth scale & 2 & 4 & 3 & $\mathrm{~cm}$ & $\begin{array}{l}\text { Measurement; Mölg et al. } \\
\text { (2012) }\end{array}$ \\
\hline $\begin{array}{l}\text { Surface roughness length } \\
\text { fresh snow }\end{array}$ & 0.19 & 0.29 & 0.24 & $\mathrm{~mm}$ & Gromke et al. (2011) \\
\hline $\begin{array}{l}\text { Surface roughness length } \\
\text { firn }\end{array}$ & 1.5 & 6.5 & 4 & $\mathrm{~mm}$ & $\begin{array}{l}\text { Brock et al. (2006); Mölg et } \\
\text { al. (2012) }\end{array}$ \\
\hline $\begin{array}{l}\text { Surface roughness length } \\
\text { ice }\end{array}$ & 0.7 & 2.7 & 1.7 & $\mathrm{~mm}$ & $\begin{array}{l}\text { Cullen et al. (2007); Brock } \\
\text { et al. (2006) }\end{array}$ \\
\hline
\end{tabular}

Given the possible range of COSIMA parameters in Table 2, a manual trial and error approach was used to obtain the optimal value of the COSIMA modeling. Afterwards, the model evaluation of COSIMA is conducted for the ablation period (from 1 May to 31 August 2018). The visual comparison is presented in Figure 3 for AWS1. The comparison against the observation from AWS1 reveals a good agreement of COSIMA with the measured surface temperature $(R=0.71, R M S E=2.61 \mathrm{~K})$. In terms of snow height change, there is a significant offset in the AWS1. Especially the modeled snow height not captured is after 7 August. This is partly 
attributed to the measurement error during the strongly ablation period. The sensor used to measure the distance between the surface and the sensor has also a membrane that deteriorates time and produces false values, which is a known potential problem for these instruments (Mölg et al., 2020). Otherwise the mistakes of the measured snow height could be existed during this period. The effect of snowdrift on the snow height has been reported by Li et al. (2018) for Qiangtang Glacier No.1. As strongly ablation usually occurs on Urumqi Glacier No.1 during this period (Li et al., 2021), there are few effects of snowdrift on the snow height. COSIMA overestimates the snow height at the location of AWS1. The RMSE between the daily measured and modeled snow height was $0.15 \mathrm{~m}$ over the observation period; the correlation coefficient was 0.94 .

This study carried out the comparison between the measured and modeled summer cumulative mass balance in order to validate the robustness of COSIMA performance (Fig. 4). Negative values point to ablation and decreasing surface height, while the positive values indicate accumulation and increasing surface height. During the ablation period, summer cumulative mass balance calculated using the stakes or snow pits method and COSIMA was $0.85 \mathrm{~m}$ w.e. and $-0.77 \mathrm{~m}$ w.e., respectively. This difference (i.e., $0.08 \mathrm{~m}$ w.e) is acceptable given the measured mass balance uncertainty. The modeled mass balance agreed well with the measured mass balance $\left(R_{\text {total }}=0.70 ; R S_{\text {total }}=0.43 \mathrm{~m}\right.$ w.e. $)$. The correlation coefficient $(R)$ is 0.75 and the RMSE is $0.35 \mathrm{~m}$ w.e. for the WB, while the correlation coefficient is 0.70 and RMSE is 0.49 for the EB. Such a good performance regarding the mass balance simulations makes us confident in the COSIMA's ability to capture the mass balance on Urumqi Glacier No. 1. Therefore, COSIMA in its current configuration can offer a realistic estimate of surface energy and mass balance of Urumqi Glacier No. 1 and is therefore analyzed further in the following parts.

\subsection{Glacier-wide energy balance}

Figure 5 depicts the daily heat flux for snow/ice melting $\left(Q_{\text {melt }}\right)$, net shortwave radiation $\left(S W_{\text {net }}\right)$, incoming longwave radiation $\left(L W_{\text {in }}\right)$, outgoing longwave radiation $\left(L W_{\text {out }}\right)$, sensible heat flux $\left(Q_{\text {sens }}\right)$, latent heat flux $\left(Q_{\text {lat }}\right)$ and ground heat flux $\left(Q_{\mathrm{G}}\right)$. The main energy component causing the glacier ablation were $S W_{\text {net }}(148.18$ $\left.\mathrm{W} \mathrm{m}^{-2}\right), L W_{\text {in }}\left(241.84 \mathrm{~W} \mathrm{~m}^{-2}\right)$ and $Q_{\text {sens }}\left(10.08 \mathrm{~W} \mathrm{~m}^{-2}\right)$. The main energy expenditure were the $L W_{\text {out }}(-283.11$ $\left.\mathrm{W} \mathrm{m}^{-2}\right), Q_{\text {lat }}\left(-5.93 \mathrm{~W} \mathrm{~m}^{-2}\right)$ and $Q_{\mathrm{G}}\left(-3.41 \mathrm{~W} \mathrm{~m}^{-2}\right)$.

Generally, $S W_{\text {net }}$ dominated the the heat flux for snow/ice melting throughout the ablation period. $S W_{\text {net }}$ tended to increase before early June and then decrease, which may be related to increased precipitation. This can increase surface albedo, and finally result in the decreasing $S W_{\text {net }}$. Acted as a heat sink, $L W_{\text {net }}$ was negative. The record of $L W_{\text {net }}$ indicated three separate phases. Relatively larger negative $L W_{\text {net }}$ occurred before the early June and after the late August. Between these two periods, $L W_{\text {net }}$ was less negative. $Q_{\text {sens }}$ constantly provided energy gain for glacier melt, because relative humidity, wind speed, and air temperature are always higher than glacier surface's. $Q_{\text {lat }}$ was negative throughout the ablation period, mainly affected by the specific humidity gradient and the relative humidity gradient, indicating that the sublimation process also existed throughout the ablation period and led to mass loss. This is because relatively lower temperatures and relative humidity led to specific humidity gradients signing from the glacier surface to the atmosphere. $Q_{\mathrm{G}}$ provided a more minor heat sink compared with other heat fluxes depending on $S W_{\text {in }}$ and glacier surface temperature. 
Table 3

Seasonal change of mass balance components during the ablation period of 2018.

\begin{tabular}{|c|c|c|c|c|c|c|c|c|c|}
\hline Month & Location & $S W_{\text {net }}$ & $L W_{\text {in }}$ & $L W_{\text {out }}$ & $L W_{\text {net }}$ & $Q_{\text {sens }}$ & $Q_{\text {lat }}$ & $Q_{G}$ & $Q_{\text {melt }}$ \\
\hline \multirow[t]{3}{*}{ May } & $\begin{array}{l}\text { Urumqi Glacier } \\
\text { No. } 1\end{array}$ & 90.23 & 216.43 & -279.21 & -62.78 & 6.48 & -17.59 & -5.62 & -12.78 \\
\hline & EB & 92.86 & 218.25 & -281.06 & -62.81 & 6.77 & -17.95 & -5.43 & -14.48 \\
\hline & WB & 85.66 & 213.23 & -275.96 & -62.73 & 5.97 & -16.96 & -5.95 & -9.80 \\
\hline \multirow[t]{3}{*}{ June } & $\begin{array}{l}\text { Urumqi Glacier } \\
\text { No. } 1\end{array}$ & 52.40 & 268.01 & -290.15 & -22.14 & 8.20 & -3.89 & 1.39 & -29.28 \\
\hline & EB & 55.57 & 270.22 & -291.51 & -21.29 & 8.47 & -3.78 & 1.38 & -32.93 \\
\hline & WB & 46.93 & 264.14 & -287.77 & -23.63 & 7.73 & -4.07 & 1.40 & -22.86 \\
\hline \multirow[t]{3}{*}{ July } & $\begin{array}{l}\text { Urumqi Glacier } \\
\text { No. } 1\end{array}$ & 52.94 & 262.04 & -288.29 & -26.26 & 9.37 & -3.17 & -1.34 & -30.76 \\
\hline & EB & 56.27 & 264.20 & -289.55 & -25.35 & 9.44 & -3.06 & -1.20 & -34.28 \\
\hline & WB & 47.18 & 258.24 & -286.1 & -27.85 & 9.25 & -3.38 & -1.58 & -24.58 \\
\hline \multirow[t]{3}{*}{ August } & $\begin{array}{l}\text { Urumqi Glacier } \\
\text { No. } 1\end{array}$ & 50.84 & 220.9 & -274.82 & -53.92 & 16.27 & 0.92 & -8.07 & -18.56 \\
\hline & $\mathrm{EB}$ & 54.42 & 222.75 & -276.68 & -53.93 & 15.87 & 0.85 & -7.84 & -20.69 \\
\hline & WB & 44.65 & 217.64 & -271.54 & -53.90 & 16.96 & 1.06 & -8.46 & -14.83 \\
\hline
\end{tabular}

\subsection{Spatial changes in modeled mass balance}

Figure 6 shows the spatial distribution of the modeled cumulative mass balance derived from COSIMA during the ablation period 2018. Spatially, the glacier mass balance ranged from 0.23 to $-2.12 \mathrm{~m}$ w.e. The significant mass loss was at the lower elevations, while mass loss decreased at higher elevations. The glacier ablation and accumulation were affected by the glacial topography. Spatial distributions of modeled mass balance were in line with the observation (Fig. 4). The spatial variation of the mass balance was influenced by slope and slope orientation. The cumulative mass balance was $-0.77 \mathrm{~m}$ w.e. during the ablation period, mass loss was mainly located on the right side of EB and WB. For the EB, the glacier melting in the western part was stronger than that in eastern part with the higher elevation and steeper, because of the mountain shadow covered. In the same time, the cumulative mass balance of the EB and WB was $-0.86 \mathrm{~m}$ w.e. and $-0.52 \mathrm{~m}$ w.e., respectively, showing mass loss of EB was more obvious than that of WB.

\subsection{Seasonal specific mass balance components}

Urumqi Glacier No. 1 is a typical summer-accumulation type glacier and the ablation and accumulation mainly take place simultaneously in the ablation period. The annual mass balance is significantly related to the summer mass balance (Liu and Han, 1992; Li et al., 2011; Wang et al., 2016), therefore it is necessary and important to study the modeled mass balance over Urumqi Glacier No.1 during the ablation period. Moreover, 
the individual components of the glacier mass gain and loss were also derived from COSIMA. As formulated by COSIMA, the mass balance is composed of solid precipitation, sublimation, refreezing, surface melt, subsurface melt and deposition. Figure 7 shows the glacier-wide daily mass balance components. In general, the mass loss was significantly dominated by the surface melt with a value of $-0.73 \mathrm{~m}$ w.e., and then subsurface melt with a value of $-0.17 \mathrm{~m}$ w.e. (Table 4). The melting showed an increasing trend during May to July. Sublimation resulted in mass loss of $0.03 \mathrm{~m}$ w.e. during ablation period and mainly occurred in May. Although several studies have shown that the sublimation in the ablation period was smaller than in the cold season because of the dry environment, our result about sublimation was significantly smaller compared with other continental glaciers (Yang et al., 2013; Zhu et al., 2018).

Mass gain was derived from solid precipitation with a contribution of $0.19 \mathrm{~m}$ w.e., which mainly occurred from June to August. Refreezing contributed to mass gain could be neglected during the ablation period. Whether refreezing leads to mass gain during cold season provides an important internal mass storage component, which need to be further studied. However, refreezing cannot be neglected when modeling the mass balance of extreme continental glacier. The instant refreezing in the Xiao Dongkemadi Glacier in the central Tibetan Plateau, Muztag Ata No.15 Glacier in the eastern Pamir and Muji Glacier in the Pamir accounted for 20\%, 26\% and $29.4 \%$, respectively (Fujita and Ageta, 2000; Zhu et al., 2018, 2020). In summary, the long-term energy and mass balance modeling in the Tien Shan was lacking compared with the Tibetan Plateau, and the importance of sublimation and refreezing in the mass balance components cannot be determined quantitatively. 
Table 4

Seasonal change of mass balance components during the ablation period of 2018.

\begin{tabular}{|c|c|c|c|c|c|c|c|}
\hline \multirow[t]{2}{*}{ Month } & \multirow[t]{2}{*}{ Location } & $\begin{array}{l}\text { Solid } \\
\text { precipitation }\end{array}$ & Refreezing & $\begin{array}{l}\text { Surface } \\
\text { melt }\end{array}$ & $\begin{array}{l}\text { Subsurface } \\
\text { melt }\end{array}$ & Sublimation & Deposition \\
\hline & & (m w.e.) & (m w.e.) & (m w.e.) & (m w.e.) & (m w.e.) & (m w.e.) \\
\hline \multirow[t]{3}{*}{ May } & $\begin{array}{l}\text { Urumqi } \\
\text { Glacier } \\
\text { No. } 1\end{array}$ & 0.04120 & 0.00002 & -0.10665 & -0.05355 & -0.01742 & -0.00026 \\
\hline & EB & 0.04384 & 0.00002 & -0.12124 & -0.05922 & -0.01777 & -0.00025 \\
\hline & WB & 0.03742 & 0.00002 & -0.08134 & -0.04361 & -0.01679 & -0.00024 \\
\hline \multirow[t]{3}{*}{ June } & $\begin{array}{l}\text { Urumqi } \\
\text { Glacier } \\
\text { No. } 1\end{array}$ & 0.04727 & 0.00019 & -0.22723 & -0.04102 & -0.00464 & -0.00109 \\
\hline & EB & 0.04591 & 0.00018 & -0.25621 & -0.04604 & -0.00456 & -0.00109 \\
\hline & WB & 0.05077 & 0.00021 & -0.17743 & -0.03220 & -0.00480 & -0.00108 \\
\hline \multirow[t]{3}{*}{ July } & $\begin{array}{l}\text { Urumqi } \\
\text { Glacier } \\
\text { No. } 1\end{array}$ & 0.05371 & 0.00038 & -0.24716 & -0.04102 & -0.00399 & -0.00099 \\
\hline & EB & 0.05150 & 0.00038 & -0.27535 & -0.04572 & -0.00387 & -0.00098 \\
\hline & WB & 0.05792 & 0.00039 & -0.19787 & -0.03277 & -0.00421 & -0.00102 \\
\hline \multirow[t]{3}{*}{ August } & $\begin{array}{l}\text { Urumqi } \\
\text { Glacier } \\
\text { No. } 1\end{array}$ & 0.04811 & 0.00023 & -0.14989 & -0.03198 & -0.00191 & -0.00278 \\
\hline & EB & 0.04281 & 0.00026 & -0.16647 & -0.03603 & -0.00188 & -0.00268 \\
\hline & WB & 0.05763 & 0.00019 & -0.11986 & -0.02487 & -0.00196 & -0.00296 \\
\hline \multirow[t]{3}{*}{$\begin{array}{l}\text { From } \\
\text { May to } \\
\text { August }\end{array}$} & $\begin{array}{l}\text { Urumqi } \\
\text { Glacier } \\
\text { No. } 1\end{array}$ & 0.19029 & 0.00082 & -0.73093 & -0.16757 & -0.02796 & -0.00512 \\
\hline & EB & 0.18406 & 0.00084 & -0.81927 & -0.18701 & -0.02808 & -0.00500 \\
\hline & WB & 0.20374 & 0.00081 & -0.57650 & -0.13345 & -0.02776 & -0.00530 \\
\hline
\end{tabular}

\subsection{Altitudinal distribution of modeled mass balance}

Figure 8 compares the modeled and measured summer mass balance during the ablation period of 2018 as a function of elevation. The modeled mass balance well agreed with the measured mass balance, except for a discernible underestimation at the glacier terminus ranging from $3800 \mathrm{~m}$ a.s.l to $3900 \mathrm{~m}$ a.s.l. The change in the modeled mass balance with altitude during the ablation period can be divided into three stages (Fig. 8a): mass balance tended to decrease and then increased in the altitude range 3800-3900 m a.s.l.; mass balance decreased gradually above $3900 \mathrm{~m}$ a.s.l.; mass balance was more positive in the altitude range $4150-4500 \mathrm{~m}$ a.s.I. The equilibrium line altitude was at $4150 \mathrm{~m}$ a.s.I. The absolute values of surface melt decreased with 
increasing altitude (Fig. 8a), and ranged from $-1.6 \mathrm{~m}$ w.e. at the glacier terminus ( $3800 \mathrm{~m}$ a.s.l.) to $0.1 \mathrm{~m}$ w.e. at the top of the glacier (4250 $\mathrm{m}$ a.s.I.). Mass balance of EB and WB as a function of elevation in-depth analyses should be helpful to shed light on the details of mass balance. Glacier ablation mainly occurred below $4150 \mathrm{~m}$ a.s.I. and the mass balance of EB was also lager than that of WB (Fig. 8b, c).

Figure $8 \mathrm{~d}$ shows the altitudinal distribution of the averaged mass balance components. Obviously, solid precipitation and glacier melt (including surface melt and subsurface melt) during the ablation period were prominent components of mass balance, whereas refreezing, deposition and sublimation were less dominant. On average, surface melt significantly dominated the glacier mass loss, and then subsurface melt. Mass loss by way of sublimation could be negligible. On the other hand, the mass gain was mainly due to solid precipitation. Meanwhile, refreezing and deposition were especially close to zero with little variations.

\subsection{Error analysis for COSIMA}

The uncertainties of input parameters in the process of energy mass balance calculation can influence COSIMA results, which need to be considered. At Urumqi Glacier No. 1, uncertainties of input parameters are associated with the albedo, surface roughness length, vertical gradient for precipitation and lapse rate for air temperature (Table 6 in Appendix B). 10 scenarios for parameter sensitivity tests are set by perturbing one parameter and keeping other parameter unchanged.

Figure 9 shows the evaluation of parameter uncertainty in the COSIMA. The sensitivity of mass balance to vertical gradient for precipitation was lower than that of lapse rate for air temperature. The lapse rate for air temperature increased (or decreased) by $10 \%$ results in mass balance change with 0.012 (or 0.010 ) $\mathrm{m}$ w.e., and the vertical gradient for precipitation $\pm 10 \%$ produced less than $1 \mathrm{~mm}$ w.e. of mass loss. The highest parameter sensitivity was related to ice albedo. The sensitivity for fresh snow albedo was higher than the firn snow. When ice albedo increased (or decreased) by $10 \%$, a mass loss (or gain) of $-0.50(0.41) \mathrm{m}$ w.e. occurred on Urumqi Glacier No. 1, which was similar with the results on the Zhadang Glacier (Mölg et al., 2012). Changes in the albedo depth scale also have significant effects on mass balance compared with albedo time scale. When the albedo depth scale increased (or decreased) by $10 \%$, the modeled mass gain (or loss) was $0.013(-0.015) \mathrm{m}$ w.e. The albedo time scale increased (or decreased) by $10 \%$ results in mass balance change of -0.003 (or 0.004 ) $\mathrm{m}$ w.e. Moreover, we also evaluated sensitivity of surface roughness length, such as surface roughness length ice, firn snow and fresh snow, indicating that the effect of surface roughness length on mass balance can be neglected.

\section{Discussion}

\subsection{Parametrization of the surface energy fluxes}

The $S W_{\text {net }}$ is an important source of energy for glaciers. It is determined by $S W_{\text {in }}$ and albedo of the glacier surface within the COSIMA. The albedo values for snow and ice are variable due to grain size and form, liquid water content, topographic effects, impurities, etc. (Yue et al., 2017; Cuffey and Paterson, 2010). Albedo parameterization scheme in COSIMA tries to reproduce albedo by introducing albedo of fresh snow, firn snow 
and ice, albedo time scale and albedo depth scale, which can solve exponentially decreases from fresh snow albedo to ice albedo (Oerlemans and Knap, 1998). In Fig. 10 we show the comparison between the measured and modeled albedo during the ablation period 2018. In generally, this albedo parametrizations in COSIMA were able to capture increases except early ablation period, and several studies had also used similar albedo parametrizations (e.g. Mölg et al., 2012; Huintjes et al., 2015b), nevertheless the measured albedo was much more variable than modeled albedo. Most of the measured albedo increases are associated with snowfall events (as shown in Fig. 2f). However, the drawback is that the exact amount of solid precipitation does not know, but the double critical temperature index method is adopted to deduce it from total precipitation measured at AWS1 (see section 3.1). Additionally, the faster the albedo decreases after snowfall events and the lower albedo time scale (1.1 day), indicating the faster metamorphic of snow during the ablation period and may be associated with increased ambient temperature.

Usually the $L W_{\text {net }}$ makes an important contribution to the energy exchange on the glacier surface. The $L W_{\text {net }}$ is often negative, this is because glacier surface is like as blackbody within COSIMA and atmosphere emissivity is often smaller than 1 . Schaefer et al. (2020) has reported that the variability in emissivity cannot only be explained by the variability in the cloudiness and the relative humidity may influence emissivity. The uncertainties in the change of the cloud cover might result in the large emissivity. Cloud cover as input data in COSIMA was obtained from a parametrization described by Favier et al. (2004). However, this parametrization is not unique (for instant Oerlemans, 2001). Additionally, temperature of atmosphere often emits $L W_{\text {in, }}$ however, in this study, whether the $2 \mathrm{~m}$ air temperature measured at AWS1 over the glacier surface can represent the temperature of atmosphere is still to be proved.

The turbulent fluxes are often affected by local meteorological conditions. Due to the negative

$Q_{\text {lat }}$ discussed in section 5.3 which peaked in the months prior to 8 June (Fig. 5), the resulted sublimation was also evident in the mass balance record (Fig. 7). But the air temperature remained rather low, which favored a large surface-air vapor pressure gradient, and the lower relative humidity and higher wind speeds also drive turbulence (Fig. 2a, b, c). Generally, monthly means of $Q_{\text {sens }}$ and $Q_{\text {lat }}$ were of opposite sign, but absolute values of $Q_{\text {sens }}$ were larger than $Q_{\text {lat }}$ when air temperature rose, especially after 8 June, increasing the importance of $Q_{\text {sens }}$ for surface melt (Table 3).

\subsection{Geodetic v.s. modeled melt rates}

In this study, glacier mass balance of Urumqi Glacier No.1 was modeled using the AWS1-driven COSIMA during the ablation period in 2018. the mean surface velocity in the same investigative period was $0.026 \mathrm{~m}$ $\mathrm{d}^{-1}$ corresponds to $3.3 \mathrm{~m} \mathrm{yr}^{-1}$, which was derived by the comparison of two high-resolution UAV photogrammetries (Wang et al. 2021). Assuming no significant speed up during the ablation period and considering the $30 \mathrm{~m}$ spatial resolution of COSIMA, the dynamical change can be neglected for modeling at seasonal timescales due to derived small surface velocities. Figure 11a shows a comparison between the modeled results using COSIMA within this study and the geodetic results from Wang et al. (2021) based on repeated high-resolution UAV photogrammetries. Since different densities for snow, firn, and ice were used within COSIMA, we employed an average ice density of $900 \pm 17 \mathrm{~kg} \mathrm{~m}^{-3}$ for the conversion from surface elevation changes to mass changes in COSIMA. Wang et al. (2021) used in-situ measured densities of firn- 
snow data (change in ice thickness) to estimate the single-point density conversion of $752 \pm 34 \mathrm{~kg} \mathrm{~m}^{-3}$ during the ablation period of 2018. The accuracy was within decimeter accuracy, with a mean value of $0.14 \mathrm{~m}$ for the ablation period. Such decimeter-scale uncertainty supports the acquisition of the glacier elevation changes derived from COSIMA. Figure 11b shows that profiles of differences between surface elevation changes derived using COSIMA and repeated UAV surveys. Overall, both agreed well with each other, but the difference still existed ( $R=0.56$; Std dev=0.54). Repeated UAV surveys observed glacier thinning even in the upperelevation areas, while COSIMA estimated a gain of mass in the upper-elevation areas and a loss of mass in the ablation area. Differences between both datasets at the middle part are small, while high differences occur at the glacier tongues. The latter is caused by a constant ice flow into this branch over time. Surface velocity is larger in the middle-lower part than in upper stream (Wang et al., 2018). By comparison, the geodetic results of Wang et al. (2021) indicated a stronger thickening in some upper parts, which might be compensated by stronger thinning in the lowest regions compared to this study. The modeled melt rates in this study ranged from 0.2 to $1.7 \mathrm{~cm}$ w.e. $d^{-1}$ in the ablation period of 2018 with the mean value of $0.6 \mathrm{~cm}$ w.e. $\mathrm{d}^{-1}$. According to Xu et al. (2019), the melt rates of 0.9 and $0.8 \mathrm{~cm}$ w.e. $\mathrm{d}^{-1}$ were derived from long-range terrestrial laser scanning measurements in the ablation periods of 2015 and 2016 on Urumqi Glacier No.1, respectively, indicating the slightly reduced mass loss in recent year together with our modeled results. This phenomenon was also founded in Li et al. (2021).

\subsection{Sensitivity of mass balance to air temperature and precipitation}

To assess the sensitivity of the mass balance of the Urumqi Glacier No.1 to climatic factors, various air temperature or precipitation changes as input data were applied to run COSIMA over the ablation period of 2018. Eight independent air temperature change scenarios were established by perturbing air temperatures adjusted in $0.5 \mathrm{~K}$ steps from $-2 \mathrm{~K}$ to $2 \mathrm{~K}$ while keeping other variables and COSIMA parameters unchanged. In the same way, eight independent precipitation change scenarios were also designed with the change of precipitation within $10 \%$, ranging from $-40-40 \%$. The COSIMA was run under the background of these sixteen scenarios as a sensitivity analysis and the results are presented in Figure 12. The sensitivity of mass balance to increasing air temperature was higher than that to increasing precipitation on Urumqi Glacier No.1, and the dependence of mass balance on changes in air temperature and precipitation was close to linear. However, this does not mean that air temperature is more important than precipitation for controlling changes in mass balance. It only shows that the mass balance will change accordingly when the air temperature changes by 1 $\mathrm{K}$ or the precipitation changes by $10 \%$. To roughly keep the mass balance on the Urumqi Glacier No.1, $1 \mathrm{~K}$ increase in air temperature would have to be compensated by at least $40 \%$ precipitation change in our study. Compared with Che et al. (2019), our sensitivity analysis has significant advantages. On the one hand, it is forced by AWS1 on the glacier surface and can accurately show glacio-meteorological conditions. On the other hand it can more accurately reflect sensitivity analysis using detailed COSIMA coupled surface and subsurface mass balance process together.

For the continental Haxilegen Glacier No.51, mass balance was more sensitive to $1 \mathrm{~K}$ air temperature change than to a 65\% precipitation change (Zhang et al., 2018). When air temperature of the Qiyi Glacier increased by $1 \mathrm{~K}$, the equilibrium line altitude (ELA) increased by $172 \mathrm{~m}$, while the precipitation increased by $10 \%$, the ELA

Page 15/37 
decreased by $62 \mathrm{~m}$ (Wang et al., 2011). After air temperature increased by $1 \mathrm{~K}$, the mass loss of the extreme continental glaciers such as Abramov, Shumskiy, Tsentralniy, Tuyuksuyskiy and Golubina glacier was similar to a $23 \%$ increase of precipitation (Liu and Liu, 2015). However, the mass loss after a $1 \mathrm{~K}$ change temperature in Muji glacier needs to be compensated for by increasing precipitation by approximately $39 \%$ (Zhu et al., 2020). To roughly maintain the mass balance of the Shiyi glacier, a $1 \mathrm{~K}$ increase in air temperature must be compensated by at least 35\% of the precipitation changes (Zhang et al., 2020). The Parlung Glacier No. 94 as one of the maritime glaciers, its mass balance was approximately $2 \sim 3$ times more sensitive to $1 \mathrm{~K}$ temperature change than to $30 \%$ precipitation change (Yang et al., 2013). Although there are significant differences in the sensitivity of different types of glaciers to air temperature and precipitation, extreme continental glaciers have a lower percentage increase than precipitation required for maritime glaciers in order to balance the effects of a $1 \mathrm{~K}$ temperature increase.

\subsection{Using sensitivity to assess how climatic factors control the mass balance change}

Based on the method, mass balance on Urumqi Glacier No.1 is considered to be more strongly controlled by ablation period air temperature than by annual precipitation, because the sensitivity of air temperature on mass balance change (149 $\mathrm{mm}$ w.e.) is larger than annual precipitation on mass balance ( $91 \mathrm{~mm}$ w.e.). Similar results found that the mass loss from increasing in air temperature was significantly higher than that from compensating in precipitation in Urumqi Glacier No.1 based on air temperature and annual precipitation during the period of 1958-2015 (Che et al., 2019). Therefore, it is deduced that the glacier mass loss in Urumqi Glacier No.1 was mostly resulted from increasing in air temperature.

We present the studies about the control of air temperature or precipitation on mass balance in the western China together with our results in Figure. 13. The difference between mass balance changes at single glacier strongly underlines the controlling of climatic on mass balance, and presents the response of glaciers to climate. We calculate more negative mass balances corresponding with controlling of air temperature in the Zhadang Glacier and Palung Glacier No.94, which was mainly influenced by the stronger monsoon. The smallest mass loss is observed at the Muztag Ata Glacier No.15 and Muji Glacier in the eastern and northeastern Pamir regions due to the strengthening westerlies with controlling of precipitation. The mass loss of the Urumqi Glacier No.1 was similar to that of the Haxilegen Glacier No.51, and a statistically significant relationship in mass balance has also been identified (Zhang et al., 2018). Mass loss of them could be attributed to air temperature rise during the ablation period. For Urumqi Glacier No.1, the former combined with ice temperature increase and albedo reduction on the glacier surface must be considered together, however, theses physical mechanisms could also be suitable for the Haxilegen Glacier No.51, because the two glaciers are situated in the eastern Tien Shan with a relatively dry continental climate. In conclusion, the intensity of air temperature and precipitation controlling mass balance is various in different regions. The mass loss of these glaciers is mainly controlled by air temperature except the Muztag Ata No.15 Glacier and Muji Glacier, the mass balance of which are mainly dominated by the annual precipitation.

\subsection{Comparison to previous studies of mass balance in Urumqi Glacier No. 1}


Figure 14 shows the comparison of our results with the glaciological mass balance, Degree-day model and geodetic method results on Urumqi Glacier No.1. The mass balance obtained by different methods compares with glaciological mass balance to clearly present the optimal model performance. The energy balance model is usually regarded as reference model in calculating mass balance. Che et al. (2011) conducted an energy balance modeling experiment forcing by AWS2 datasets and the result was in line with actual observation. The relative coefficient between the modeled and measured cumulative mass balance was 0.86 , and the coefficient of determination was 0.75 (Che et al., 2019). The Degree-day model was more suitable for longterm mass balance estimates, because overall mass balance estimates were in a good agreement with glaciological mass balance for the long term (Wu et al., 2011). In term of the enhanced Degree-day model, the spatial distribution of mass balance in Urumqi Glacier No.1 showed that the performance was less performed compared with the glaciological mass balance (Huintjes et al., 2010).

There was actual phenomenon that annual mass balance was mainly related to summer mass balance (mass balance in the ablation period) in Urumqi Glacier No.1 (Li et al., 2011; Wang et al., 2016). As shown in Fig. 14, our result was more consistent with annual glaciological mass balance compared with Che et al. (2019). The hourly meteorological records and COSIMA combined with surface and subsurface processes together produce this optimal result. It is therefore regarded as more accurately reflect energy and mass balance process on glacier surface. Geodetic mass balance in ablation period of 2015 and 2016 was more negative compared with annual glaciological mass balance, while our estimate with the value of $-0.77 \mathrm{~m}$ w.e. was also more consistent with the annual glaciological mass balance. The performance of the simplified energy balance model is better than that of the Degree-day model in the short time, but the Degree-day model performed better than the simplified energy balance model in the same zone (e.g. the zone around the ELA) (Li, 2020).

We collect the model comparison studies during ablation period and assess their difference in space and time. Some studies reveal the enhanced Degree-day model offering significant improvements over the classical Degree-day model at the point scale, nevertheless the improvement was limited (Pellicciotti et al., 2005). However, at the glacier scale, the result is less clear. Pellicciotti et al. (2013) showed that there were obvious differences in performance between the enhanced Degree-day model and an energy balance model. MacDougall et al. (2011) also applied an energy balance model and four empirical models, and similar conclusions were obtained. The two models can be demonstrated to be clearly superior to others, and their performance strongly depends on input data and temporal and spatial resolution of the application. For the enhanced Degree-day model, the input meteorological variables need to be extrapolated from point observations to the grid cells of the glacier, as the energy mass balance require a number of input meteorological variables. Some of these, such as wind speed or shortwave radiation, are difficult to model at glacier surface, and extrapolation methods also fail, especially wind speed, because this cannot be identified due to no clear elevation or spatial dependency. It is not clear which is superior at whole-glacier and larger scales between the two models. At Urumqi Glacier No.1, the both performances have not compared with glaciological mass balance as yet. The results presented here are important, since some studies have shown that the modeled mass balance affects runoff projections (Gabbi et al., 2014).

Our study is the first attempt to evaluate the performance of mass balance at Urumqi Glacier No.1 by linking COSIMA with the in-situ measured meteorological records and to understand glacier energy and mass balance 
process. Our estimate result is consistent with glaciological mass balance (Fig. 3), and similar with annual glaciological mass balance (Fig. 14). However, our study is limited in time scale and the insight into for model performance, such as parameter instability. In future, we plan to extend the input data time series using the ERA-5 reanalysis data, particularly with regard to glacier projections.

\section{Conclusions}

Based on the meteorological measurements in AWS on the surface of Urumqi Glacier No.1 in the Chinese Tien Shan during the ablation period 2018, the temporal variations in energy and mass balance and the response of mass balance to climate variations, were investigated using COSIMA. The optimization of our modeled results is not suitable for traditional optimization method (e.g. Monte-Carlo approach) because of the shortterm investigated period. Therefore, we attempted to find the best parameter selection for AWS1. The manual model optimization conducted to meet the climatic observations from AWS1, afterwards, the model evaluation of COSIMA was conducted using surface temperature, snow height and glacier-wide mass balance measurements.

Relative humidity was small while wind speed was high prior to 8 June, but air temperature remained rather low and surface temperature rose. These meteorological conditions will drive turbulence. The main components in energy balance were radiation components ( $S W_{\text {net }}$ and $\left.L W_{\text {net }}\right)$ and turbulent fluxes during ablation period. Albedo as a key parameter could affect $S W_{\text {net, }}$ and most of the measured increases in albedo can be associated with precipitation events. Surface melt and solid precipitation were two dominant components of mass balance. Most surface melt and solid precipitation occurred simultaneously in JuneAugust with the strongest mass losses in July. Urumqi Glacier No.1 experienced a significant mass loss, with an average value of $-0.77 \mathrm{~m}$ w.e. corresponds to $0.6 \mathrm{~cm}$ w.e. $\mathrm{d}^{-1}$ over ablation period 2018. Comparing with the UAV results at Urumqi Glacier No.1 during the same period showed that the modeled surface elevation change agreed well with surface elevation change determined by repeated UAV surveys. By comparing this result with the geodetic mass balance observations of Urumqi Glacier No.1 for ablation periods of 2015 and 2016, it is indicated the slightly reduced mass loss was experienced in recent year.

Sensitivity analysis showed that the sensitivity of temperature is greater than precipitation, and mass loss caused by temperature increase of $1 \mathrm{~K}$ needed to be compensated by at least $40 \%$ precipitation. The air temperature during ablation period was more important than annual precipitation in controlling mass balance changes on Urumqi Glacier No.1. The key of performance of the energy balance model depended on the accurate of meteorological records and optimization of parameters. In general, the COSIMA can reproduce the glaciological mass balance compared with geodetic method and other energy balance model. The Degree-day model was more suitable for long-term mass balance estimates, and the performance of the simplified energy balance model was better than that of the Degree-day model in the short time. However, at the glacier-wide scale, it is difficult to identify which is better between the enhanced Degree-day model and energy balance models, that is because it strongly depends on input data.

\section{Declarations}


Acknowledgements. This research was jointly funded by the National Natural Science Foundation of China (grant no. 41771077), the Youth Innovation Promotion Association of CAS, the Strategic Priority Research Program of Chinese Academy of Sciences (grant no. XDA20020102), National Natural Science Foundation of China (grant no. 42001067)『and the State Key Laboratory of Cryospheric Science (grant no. SKLCS-ZZ-2020).

\section{References}

1. Anderson, E.A., 1976. A point energy and mass balance model of a snow cover. Technical Report NWS19, NOAA.

2. Bintanja, R., S. Jonsson, W. H. Knap, 1997. The annual cycle of the surface energy balance of Antarctic blue ice, J. Geophys. Res., 102(D2),1867-1881, doi:10.1029/96JD01801.

3. Bintanja, R., van den Broeke, M., 1995. The surface energy balance of Antarctic snow and blue ice. J. Appl. Meteorol., 34: 902-926.

4. Brock, B.W., Willis, I.C., Martin, M.J., 2006. Measurement and parameterization of aerodynamic roughness length variations at Haut Glacier d'Arolla, Switzerland. J. Glaciol., 52: 281-297.

5. Braithwaite, R.J., 1995. Aerodynamic stability and turbulent sensible heat flux over a melting ice surface, the Greenland ice sheet. J. Glaciol., 41: 562-571.

6. Che, Y. J., Zhang, M. J., Li, Z. Q., Wei, Y. Q., Nan, Z. T., Li, H. L., Wang, S. J., Su, B., 2019. Energy balance model of mass balance and its sensitivity to meteorological variability on Urumqi River Glacier No.1 in the Chinese Tien Shan. Sci Rep. 9(1):13958. doi: 10.1038/s41598-019-50398-4.

7. Cullen, N.J., Mölg, T., Kaser, G., Steffen, K., Hardy, D.R., 2007. Energy-balance model validation on the top of Kilimanjaro, Tanzania, using eddy covariance data. Ann. Glaciol., 46: 227-233.

8. Cullen, N. J., Mölg, T., Conway, J., Steffen, K., 2014. Assessing the role of sublimation in the dry snow zone of the Greenland ice sheet in a warming world. J. Geophys. Res.-Atmos. 119(11), 6563-6577. doi: 10.1002/2014JD021557

9. Cuffey, K., Paterson, W., 2010. The Physics of Glaciers, Elsevier, 4th Edn.

10. Favier, V., Wagnon, P., Chazarin, J. P., Maisincho, L., Coudrain, A., 2004. One year measurements of surface heat budget on the ablation zone of Antizana Glacier 15, Ecuadorian Andes. J. Geophys. Res., 109(D18), https://doi.org/10.1029/2003JD004359.

11. Farinotti, D., Longuevergne, L., Moholdt, G., Duethmann, D., Mölg, T., Bolch, T., Vorogushyn, S., Güntner, A., 2015. Substantial glacier mass loss in the Tien Shan over the past 50 years. Nat. Geosci., 8(9): 716-722, https://doi.org/10.1038/NGEO2513, 2015.

12. Fujita, K., Ageta, Y., 2000. Effect of summer accumulation on glacier mass balance on the tibetan plateau revealed by mass-balance model. J. Glaciol., 46(153), 244-252.

13. Gabbi, J., Carenzo, M., Pellicciotti, F., Bauder, A., Funk, M. 2014. A comparison of empirical and physically based glacier surface melt models for long-term simulations of glacier response. J. Glaciol., 60(224), 1140-1154. doi:10.3189/2014JoG14J011

14. Gromke, C., Manes, C., Walter, B., Lehning, M., Guala, M., 2011. Aerodynamic roughness length of fresh snow. Boundary Layer Meteorology, 141: 21-34. 
15. Han, H. D., Ding, Y. J., Liu, S. Y., 2005. Estimation and analysis of heat balance parameters in the ablation season of debris-covered kerqikaer glacier, tianshan mountains. J. Glaciol. and Geocryology.

16. He, X. B., Ye, B. S., Ding, Y. J., 2009. Bias correction for precipitation mesuament in tanggula mountain tibetan plateau. Advances in Water Science, 20(3), 403-408.

17. Herron, M. H., Langway, C. C., 1980. Firn Densification: An Empirical Model. J. Glaciol., 25: 373-385.

18. Huintjes, E., Sauter, T., Schröter, B., Maussion, F., Yang, W., Kropáček, J., Buchroithner, M., Scherer, D., Kang, S. C., Schneider, C., 2015a. Evaluation of a coupled snow and energy balance model for Zhadang glacier, Tibetan Plateau, using glaciological measurements and time-lapse photography. Arct. Antarct. Alp. Res.

19. Huintjes, E., Neckel, N., Hochschild, V., Schneider, C., 2015b. Surface energy and mass balance at Purogangri Ice Cap, central Tibetan Plateau, 2001-2011. J. Glaciol. 61(230): 1048-1061.

20. Huintjes, E., Li, H. L, Sauter, T., Li, Z. Q., Schneider, C., 2010 Degree-day modelling of the surface mass balance of Urumqi Glacier No. 1, Tian Shan, China, The Cryosphere Discuss., 4, 207-232, https://doi.org/10.5194/tcd-4-207-2010, 2010.

21. Hock, R., Holmgren, B., 2005. A distributed surface energy-balance model for complex topography and its application to Storglaciren, Sweden. J. Glaciol., 51(172), 25-36.

22. Immerzeel, W. W., Beek, L. P. H. V., Bierkens, M. . P., 2010. Climate change will affect the Asian water towers. Science (New York, N.Y.) 328(5984), 1382-1385. doi: 10.1126/science.1183188.

23. Jiang, X., Wang, N., He, J., Wu, X., Song, G., 2010. A distributed surface energy and mass balance model and its application to a mountain glacier in China. Chinese Sci. Bull. 55 (20), 2079-2087.

24. Jia, Y. F., Li, Z. Q., Jin, S., Xu, C. H., Deng, H. J., Zhang, M. J., 2020. Runoff Changes from Urumqi Glacier No. 1 over the Past 60 Years, Eastern Tianshan, Central Asia. Water, 12(5):1286. doi:10.3390/w12051286

25. Jia, Y. F., Li, Z. Q., Xu, C. H., Jin, S., Deng, H. J., 2020. A Comparison of Precipitation Measurements with a PWS100 Laser Sensor and a Geonor T-200B Precipitation Gauge at a Nival Glacial Zone in Eastern Tianshan, Central Asia. Atmosphere, 11, 1079. https://doi.org/10.3390/atmos11101079.

26. Kaser, G., Hardy, D. R., Mölg, T., Bradley, R. S., Hyera, T. M., 2004. Modern glacier retreat on Kilimanjaro as evidence of climate change: Observations and facts, Int. J. Climatol., 24, 329-339, doi:10.1002/joc.1008.

27. Kang, E. S., Yang, D. Q., Zhang, Y. S., 1992. An experiment study of the water and heat balance in the source area of the Urumqi River in the Tian Shan Moutains. Ann. Glaciol., (16):55-66.

28. Kumar, L., Skidmore, A. K., Knowles, E., 1997. Modelling topographic variation in solar radiation in a GIS environment. Int. J. Geogr. Inf. Sci. 11(5), 475-497 (doi:10.1080/136588197242266)

29. Klok, E. J., Oerlemans, J., 2002. Model study of the spatial distribution of the energy and mass balance of Morteratschgletscher, Switzerland. J. Glaciol., 48: 505-518.

30. Liu, Q., Liu, S. Y., 2015. Response of glacier mass balance to climate change in the Tianshan Mountains during the second half of the twentieth century. Clim. Dyn. 46 (1-2), 303-316.

31. Liu, C. G., Han, T. D., 1992. Relation between recent glacier variations and climate in the Tien Shan mountains, Central Asia, Ann. Glaciol., 16, 11-16, https://doi.org/10.3189/1992AoG16-1-11-16, 1992.

32. Li, S. H., Yao, T. D., Yang, W., Yu, W. S., Zhu, M. L., 2018. Glacier energy and mass balance in the inland Tibetan Plateau: Seasonal and interannual variability in relation to atmospheric changes. J. Geophys. Res. Atmospheres, 123, 6390-6409. https://doi.org/10.1029/2017JD028120. 
33. Li, H. L., Wang, P. Y., Li, Z. Q., Jin, S., Xu, C. H., Liu, S. S., Zhang, Z. Y., Xu, L. P., 2021. An application of three different field methods to monitor changes in Urumqi Glacier No. 1, Chinese TienShan, during 2012-18. J. Glaciol., 1-13. https://doi.org/10.1017/jog.2021.71.

34. Li, H. L., 2020. Spatial and temporal transferability of Degree-Day Model and Simplified Energy Balance Model: a case study. Sci. Cold Arid Reg., 12(2): 0095-0103. Doi: 10.3724/SP.J.1226.2020.00095.

35. Li, Z. Q., Li, H. L., Chen, Y. N., 2011. Mechanisms and simulation of accelerated shrinkage of continental glaciers: a case study of Urumqi Glacier No. 1 in eastern Tianshan, central Asia. Journal of Earth Science, 22(4): 423-430. Doi: 10.1007/s12583-011-0194-5.

36. Liu, C. H., Xie, Z. C., Wang, C. Z., 1997. A research on the mass balance process of Glacier No.1 at the headwaters of the Urumqi River, Tianshan Mountains, J. Glaciol. Geocryol., 19, 17-24.

37. MacDougall, A. H., Wheler, B. A., Flowers, G. E., 2011. A preliminary assessment of glacier melt-model parameter sensitivity and transferability in a dry subarctic environment. The Cryosphere, 5(4), 1011-1028 (doi: 10.5194/tc-5-1011-2011)

38. Mölg, T., Hardy, D. R., Collier, E., Kropac, E., Schmid, C., Cullen, N. J., Kaser, G., Prinz, R., Winkler, M., 2020. Mesoscale atmospheric circulation controls of local meteorological elevation gradients on Kersten Glacier near Kilimanjaro summit. Earth Syst. Dynam., 11(3), 653-672 doi: 10.5194/esd-11-653-2020.

39. Mölg, T., Maussion, F., Yang, W., Scherer, D., 2012. The footprint of Asian monsoon dynamics in the mass and energy balance of a Tibetan glacier. The Cryosphere 6(6), 1445-1461. doi: 10.5194/tc- 6-1445-2012

40. Mölg, T., Cullen, N.J., Hardy, D.R., Winkler, M. and Kaser, G., 2009. Quantifying climate change in the tropical midtroposphere over East Africa from glacier shrinkage on Kilimanjaro. J. Clim, 22, 4162-4181.

41. Oerlemans, J., Knap, W. H., 1998. A 1 year record of global radiation and albedo in the ablation zone of Morteratschgletscher, Switzerland. J. Glaciol., 44 (147): 231-238.

42. Oerlemans, J., 2001. Glaciers and Climate Change, A.A. Balkema Publishers,Lisse, Abingdon, Exton, Tokyo.

43. Oerlemans, J., Klok, E. J., 2002. Energy balance of a glacier surface: Analysis of automatic weather station data from the Morteratschgletscher, Switzerland, Arct. Antarct. Alp. Res., 34, 477-485, doi:10.2307/1552206.

44. Pellicciotti, F., Ragettli, S., Carenzo, M., McPhee, J., 2013. Changes of glaciers in the Andes of Chile and priorities for future work. Sci. Total Environ., 493, 1197-1210 (doi: 10.1016/j.scitotenv. 2013.10.055)

45. Pellicciotti, F., Brock, B. W., Strasser, U., Burlando, P., Funk, M., Corripio, J. G., 2005. An enhanced temperature-index glacier melt model including shortwave radiation balance: development and testing for Haut Glacier d'Arolla, Switzerland. J. Glaciol., 51(175), 573-587 (doi: 10.3189/172756505781829124)

46. Pieczonka, T., Bolch, T., 2015. Region-wide glacier mass budgets and area changes for the Central Tien Shan between 1975 and 1999 using Hexagon KH-9 imagery, Global Planet. Change, 128, 1-13, https://doi.org/10.1016/j.gloplacha.2014.11.014, 2015

47. Sakai, A., Fujita, K., 2017. Contrasting glacier responses to recent climate change in high-mountain Asia, Sci. Rep., 7, 13717, https://doi.org/10.1038/s41598-017-14256-5, 2017.

48. Schaefer, M., Fonseca-Gallardo, D., Farías-Barahona, D., Casassa, G., 2020. Surface energy fluxes on Chilean glaciers: measurements and models, The Cryosphere, 14, 2545-2565. (Doi: 10.5194/tc-14-2545- 
2020)

49. Sun, W. J., Qin, X., Wang, Y. T., Chen, J. Z., Du, W. T., Zhang, T., Huai, B. J., 2018. The response of surface mass and energy balance of a continental glacier to climate variability, western Qilian Mountains, China. Clim. Dyn., 50(9/10): 3557-3570.

50. Broeke, M. V. D., As, D. V., Reijmer C, Wal, R., 2004. Assessing and improving the quality of unattended radiation observations in Antarctica. J. Atmos. Ocean. Technol, 21(9): 1417-1431.

51. Wang, P. Y., Li, Z. Q., Li, H. L., Zhang, Z. Y., Xu, L. P., Yue, X. Y., 2020. Glaciers in Xinjiang, China: Past Changes and Current Status. Water, 12(9), 2367. doi: 10.3390/w12092367.

52. Wang, N. L., Yao T. D., Xu, B. Q., Chen, A. A., Wang, W. C., 2019. Spatiotemporal Pattern, Trend, and Influence of Glacier Change in Tibetan Plateau and Surroundings under Global Warming, Bulletin of Chinese Academy of Sciences, 34(11):1220-1232. Doi: 10.16418/j.issn.1000-3045.2019.11.005

53. Wang, N. L., Wu, H. B., Wu, Y. W., Chen, A. A., 2015. Variations of the glacier mass balance and lake water storage in the Tarim Basin, northwest China, over the period of 2003-2009 estimated by the ICESat-GLAS data. Environ. Earth Sci 74(3), 1997-2008. doi: 10.1007/s12665-015-4662-6

54. Wang, P. Y., Li, Z. Q., Li, H. L., Yao, H. B., Xu, C. H., Zhou, P., Jin, S., Wang, W. B., 2016. Analyses of recent observations of Urumqi Glacier No. 1, Chinese Tianshan Mountains. Environ. Earth Sci 75(8), 720. doi: 10.1007/s12665-016-5551-3

55. Wang, P. Y., Li, Z. Q., Schneider, C., Li, H. L., Hamm, A., Jin, S., Xu, C. H., Li, H. L., Yue, X. Y., Yang, M., 2020. A Test Study of an Energy and Mass Balance Model Application to a Site on Urumqi Glacier No. 1, Chinese Tian Shan. Water, 12, 2865. https://doi.org/10.3390/w12102865.

56. Wang, P. Y., Li, Z. Q., Li, H. L., Wang, W. B., Zhou, P., Wang, L., 2017. Characteristics of a partially debriscovered glacier and its response to atmospheric warming in Mt. Tomor, Tien Shan, China. Glob. Planet. Change, 159, 11-24. doi: 10.1016/j.gloplacha.2017.10.006.

57. Wang, P. Y., Li, H. L., Li, Z. Q., Liu, Y. S., Xu, C. H., Mu, J. X., Zhang, H., 2021. Seasonal Surface Change of Urumqi Glacier No. 1, Eastern Tien Shan, China, Revealed by Repeated High-Resolution UAV Photogrammetry. Remote Sens, 13(17):3398. doi.org/10.3390/rs13173398.

58. Wang, S., Pu, J. C., Wang, N. L., 2011. Study of mass balance and sensibility to climate change of Qiyi Glacier in Qilian Mountains. J. Glaciol. and Geocryology. 33(06):1214-1221

59. Wu, L. H, Li, H. L., Wang, L., 2011. Application of a degree-day model for determination of mass balance of Urumqi Glacier No. 1, eastern Tianshan, China. J. Earth Sci. 22, 470-481. https://doi.org/10.1007/s12583-011-0201-x.

60. Xu, C. H., Li, Z. Q., Wang, P. Y., Anjum, M. N., Li, H. L., Wang, F. T., 2018. Detailed comparison of glaciological and geodetic mass balances for Urumqi Glacier No. 1, eastern Tien Shan, China, from 1981 to 2015. Cold Reg. Sci. Tech, 155, 137-148. https://doi.org/10.1016/j.coldregions.2018.08.006, 2018.

61. Xu, C. H., Li, Z. Q., Li, H. L., Wang, F. T., Zhou, P., 2019. Long-range terrestrial laser scanning measurements of annual and intra-annual mass balances for Urumqi Glacier No. 1, eastern Tien Shan, China. The Cryosphere 13, 2361-2383. doi: 10.5194/tc-13-2361-2019

62. Yao, T. D., Thompson, L., Yang, W., Yu, W. S., Gao, Y., Guo, X. J., Yang, X. X., Duan, K. Q., Zhao, H. B., Xu, B. Q., Pu, J. C., Lu, A. X., Xiang, Y., Kattel, D. B., Joswiak, D., 2012. Different glacier status with atmospheric 
circulations in Tibetan Plateau and surroundings. Nat. Clim. Chang, 2012, 2(9): 663-667.

63. Yang, W., Guo, X. F., Yao, T. D., Yang, K., Zhao, L., Li, S. H., Zhu, M. L., 2011. Summertime surface energy budget and ablation modeling in the ablation zone of a maritime Tibetan glacier. J. Geophys. Res., 2011, 116(D14):D14116.

64. Yang, W., Yao, T. D, Guo, X. F., Zhu, M. L., Li, S. H., Kattel, D. B., 2013. Mass balance of a maritime glacier on the southeast Tibetan Plateau and its climatic sensitivity. J. Geophys. Res.: Atmospheres, 118(17): 9579-9594.

65. Yang, W., Guo, X. F., Yao, T. D., Zhu, M. L., Wang, Y. J., 2016. Recent accelerating mass loss of southeast Tibetan glaciers and the relationship with changes in macroscale atmospheric circulations. Clim Dyn 47, 805-815. https://doi.org/10.1007/s00382-015-2872-y

66. Yue, X. Y, Zhao, J., Li, Z. Q., Zhang, M. J., Fan, J., Wang, L., Wang, P. Y., 2017. Spatial and temporal variations of the surface albedo and other factors influencing Urumqi Glacier No. 1 in Tien Shan, China, J. Glaciol., 63, 899-911, https://doi.org/10.1017/jog.2017.57, 2017.

67. Zhang, H., Li, Z, Q., Zhou, P., Zhu, X. F., Wang, L., 2018. Mass-balance observations and reconstruction for Haxilegen Glacier No.51, eastern Tien Shan, from 1999 to 2015. J. Glaciol., 64(247), 689-699. doi:10.1017/jog.2018.58

68. Zhang, Y., Hirabayashi, Y., Liu, S. Y., 2012. Catchment-scale reconstruction of glacier mass balance using observations and global climate data: case study of the Hailuogou catchment, south-eastern Tibetan Plateau. J. Hydrol. 444-445, 146-160.

69. Zhu, M. L., Yao, T. D., Yang, W., Xu, B. Q, Wu, G. J., Wang, X. J., Xie, Y., 2018. Reconstruction of the mass balance of Muztag Ata No. 15 glacier, eastern Pamir, and its climatic drivers. J. Glaciol., 64(244):259-274.

70. Zhu, M. L., Yao, T. D., Yang, W., Xu, B. Q, Wang, X. J., 2017. Evaluation of parameterizations of incoming longwave radiation in the high-mountain region of the Tibetan Plateau. J. Appl. Meteorol. Clim. 56 (4), 833-848.

71. Zhu, M. L., Yao, T. D., Xie, Y., Xu, B. Q., Yang, W., Yang, S., 2020. Mass balance of Muji Glacier, northeastern Pamir, and its controlling climate factors. J. Hydrol., 2020, 590(195):125447. https://doi.org/10.1016/j.jhydrol.2020.125447

72. Zhou, S. Z., Zhang, R. Y., Zhang, C., 1997. Meteorology and climatology. Beijing: Higher Education Press, 84-86.

\section{Figures}




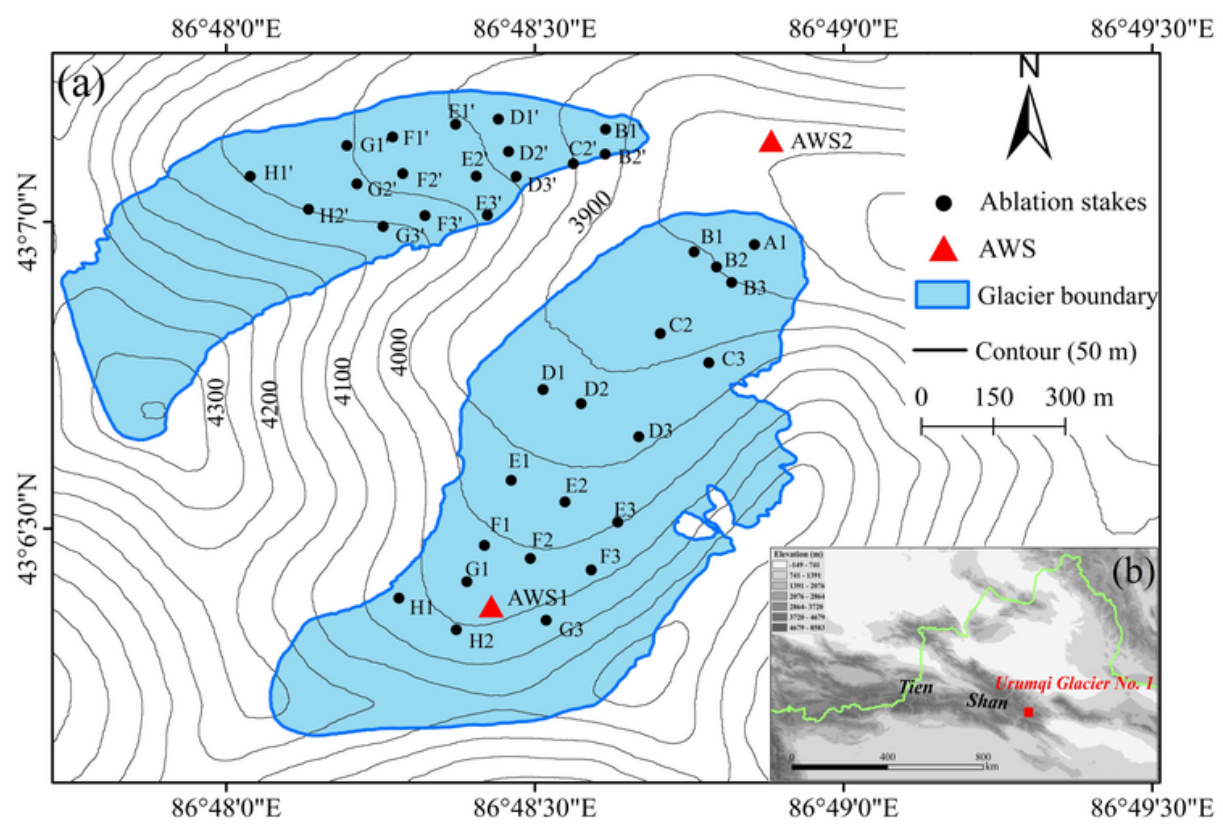

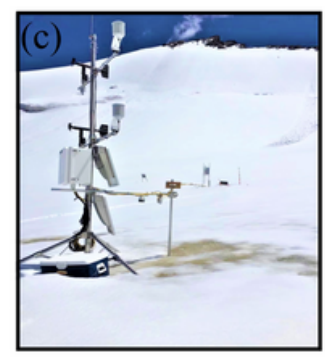

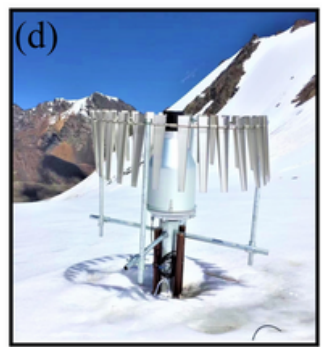

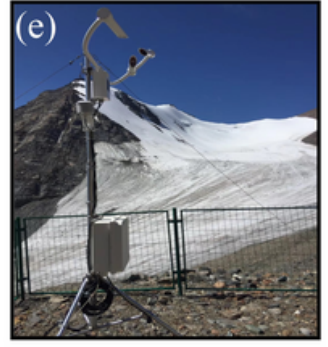

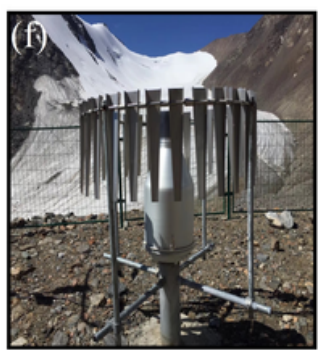

Figure 1

Overview of the study area. (a) The map of the Urumqi Glacier No. 1 showing the distribution of ablation stakes for mass balance observations by measuring stakes or snow pits, glacier boundary delineated from unmanned aerial vehicle (UAV) derived digital elevation model (DEM) on 28 August 2018 and the locations of AWS1 and AWS2). (b) Location map of Urumqi Glacier No. 1 in the eastern Tien Shan. Photographs of AWS1 (c, d) and AWS2 (e, f) taken on 21 July, 2018. 

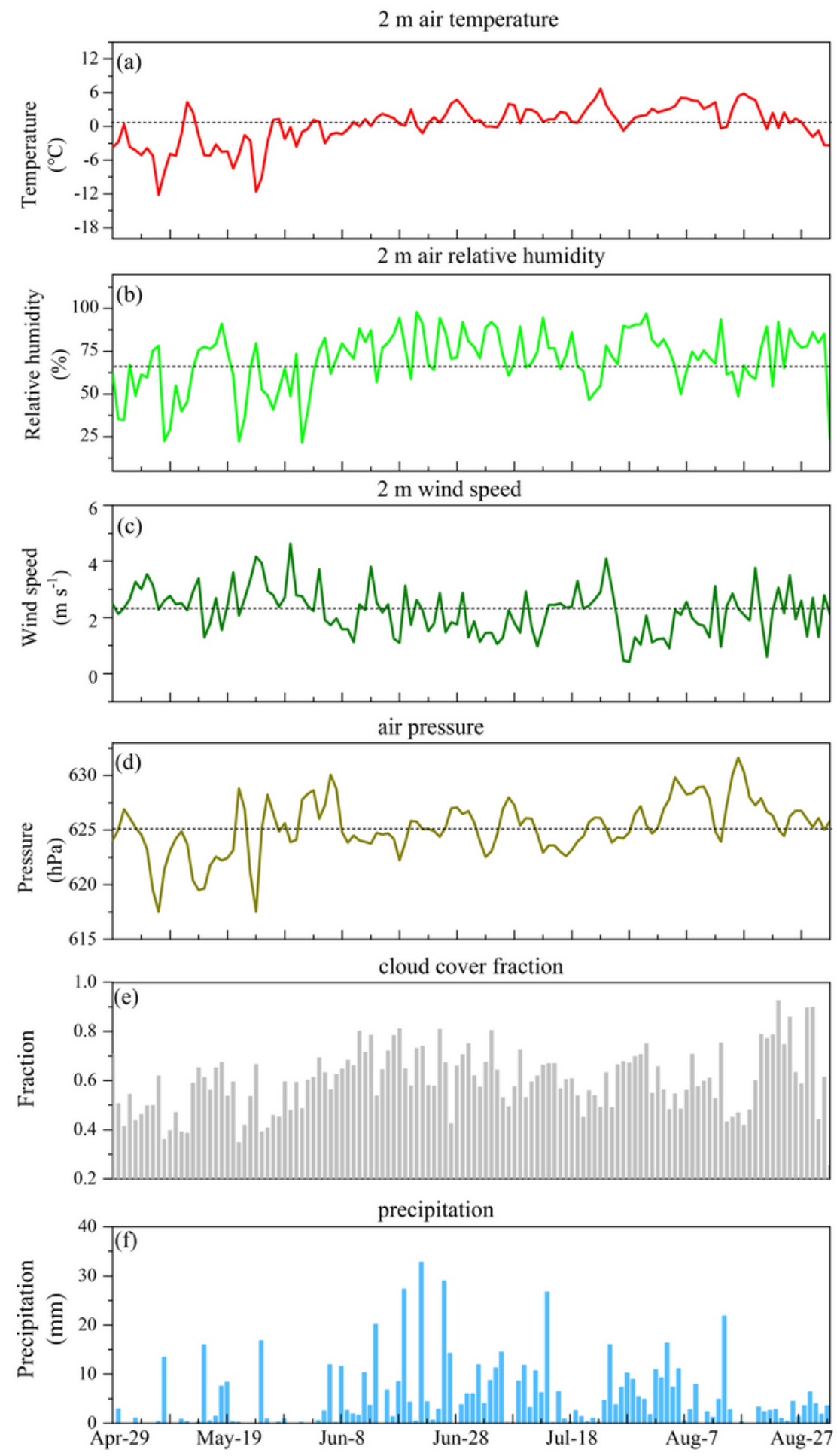

\section{Figure 2}

Daily mean values of meteorological condition during the ablation period in 2018: air temperature (a), relative humidity (b), wind speed (c), air pressure (d), cloud cover (e), and precipitation (f). 
(a)
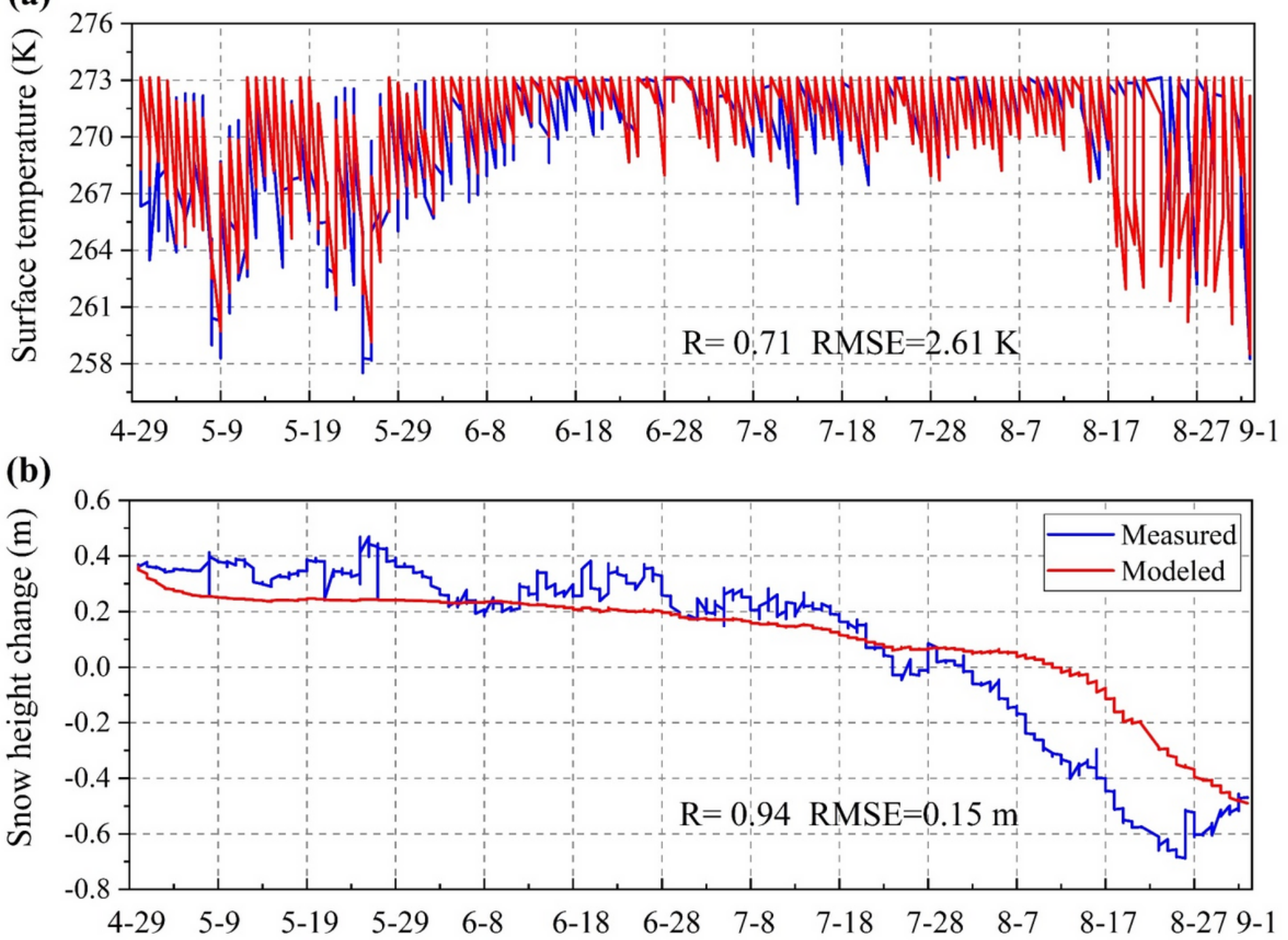

Figure 3

Model evaluation against AWS1 of hourly surface temperature (a) and accumulated hourly surface height change relative to the first time step (b). 

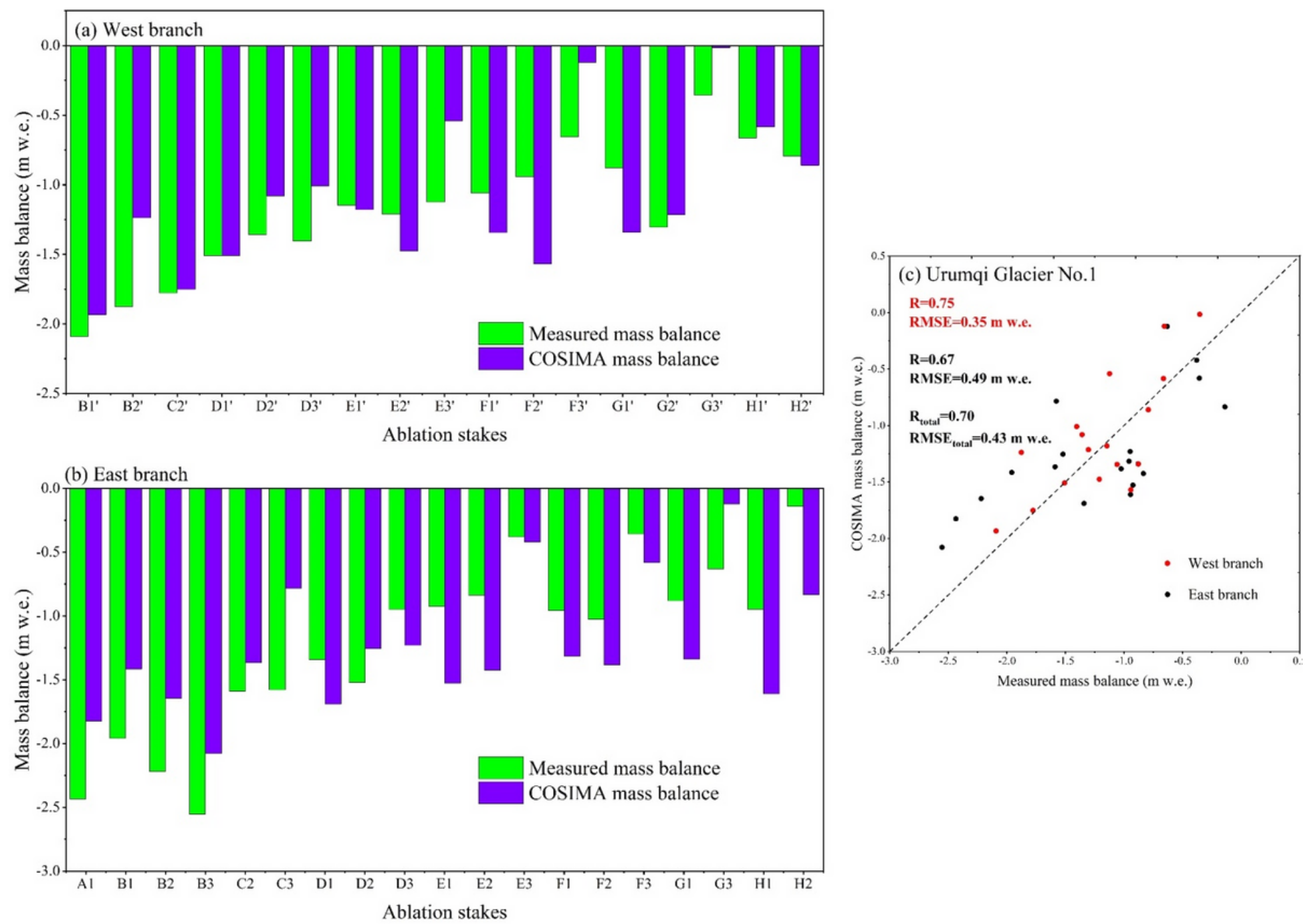

Figure 4

Comparison of glacier-wide cumulative mass balance as modeled by COSIMA and as derived from the measured average mass balance during the ablation period for the WB (a) and EB (b). The scatterplot of modeled versus measured mass balance are shown in (c) and coloring shows reference to the location of ablation stakes shown in Figure 1. The black dashed line is the 1:1 line. 


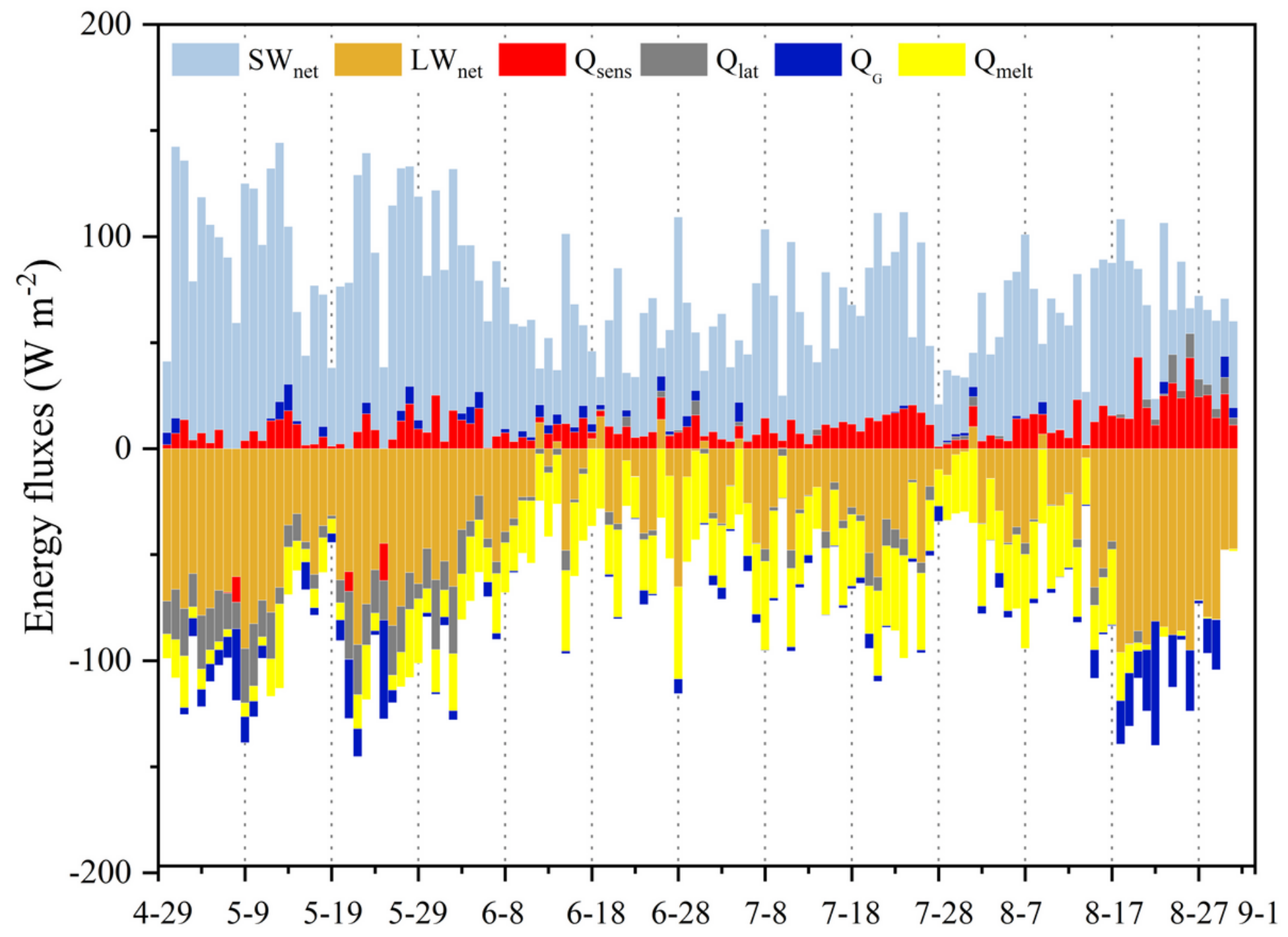

Figure 5

Glacier-wide daily surface energy balance components on the Urumqi Glacier No. 1 during the ablation period of 2018. Positive values indicate energy gain for the surface; negative ones indicate an energy loss. 


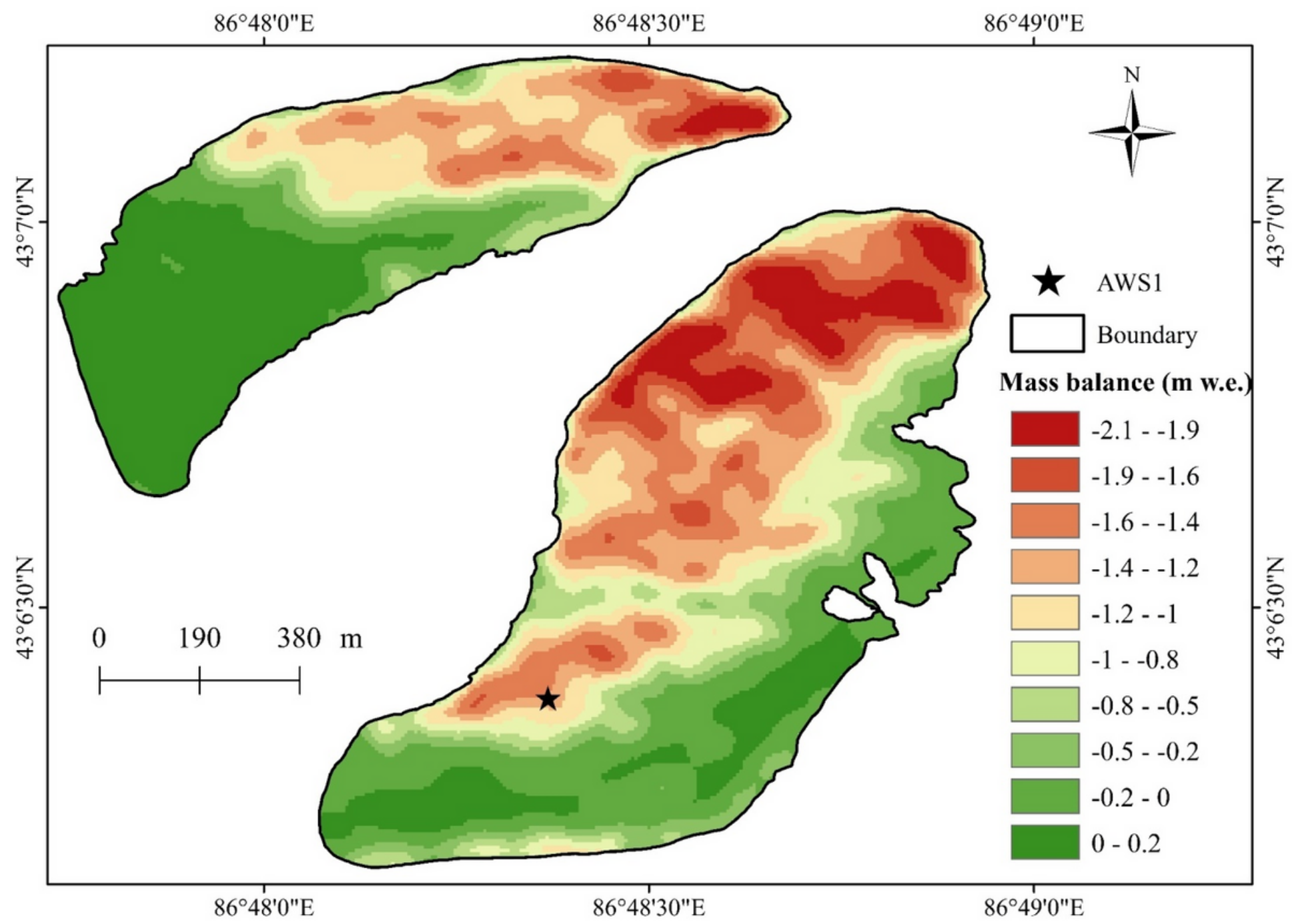

Figure 6

Spatial distribution of the modeled cumulative mass balance on the Urumqi Glacier No. 1 during the ablation period of 2018. 


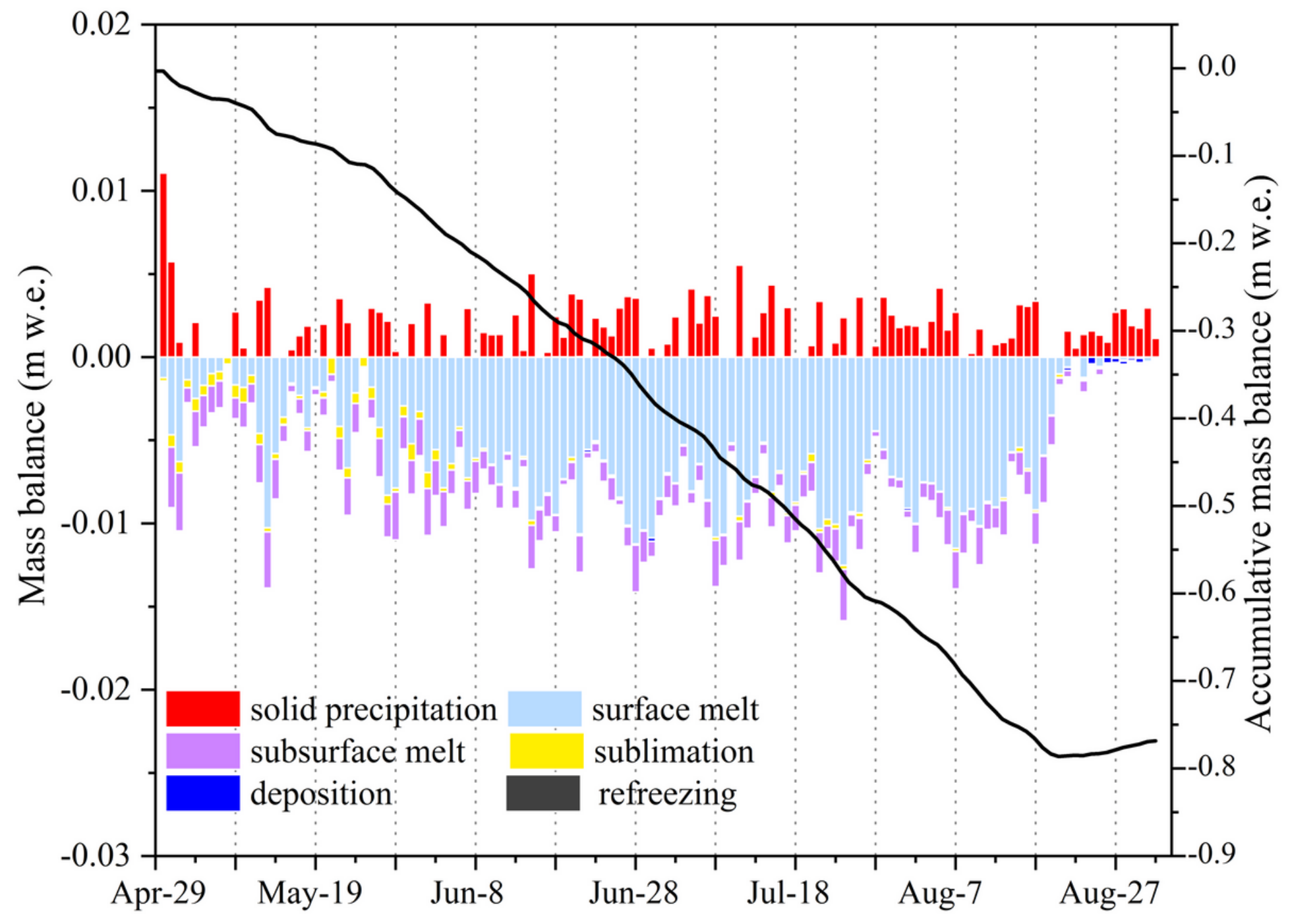

Figure 7

Glacier-wide daily mass balance components on the Urumqi Glacier No. 1 during the ablation period of 2018. 

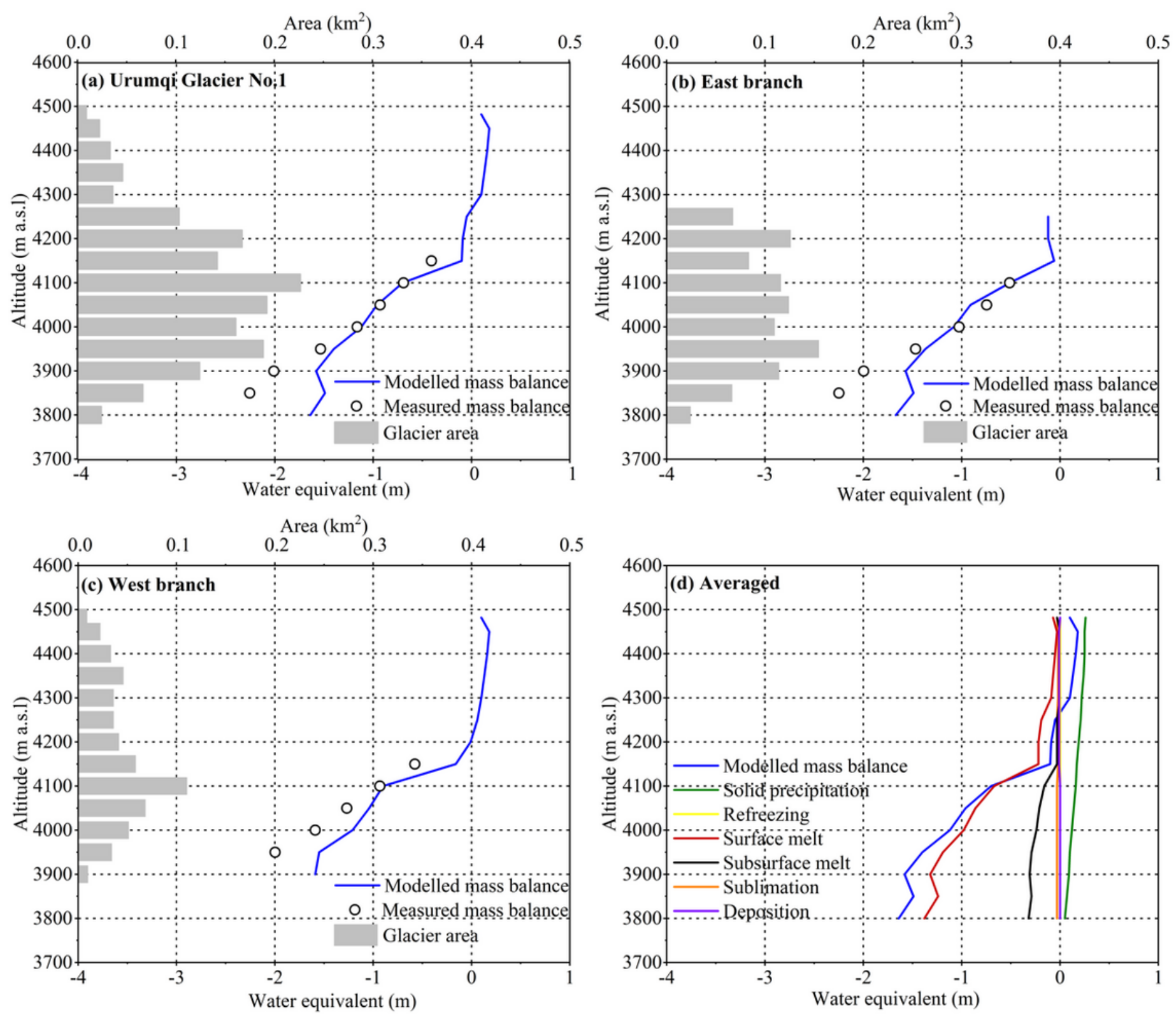

Figure 8

Comparison between measured (black circle) and modeled (blue line) mass-balance elevation distribution for the ablation period at $50 \mathrm{~m}$ altitude intervals on the Urumqi Glacier No.1 (a), East Branch (b), and West Branch (c). Grey horizontal bars illustrate the area-elevation distribution of Urumqi Glacier No.1. (d) Altitudedependent profiles of the average mass balance and its individual components for the ablation period, including surface melt, subsurface melt, sublimation, solid precipitation, refreezing and deposition. 


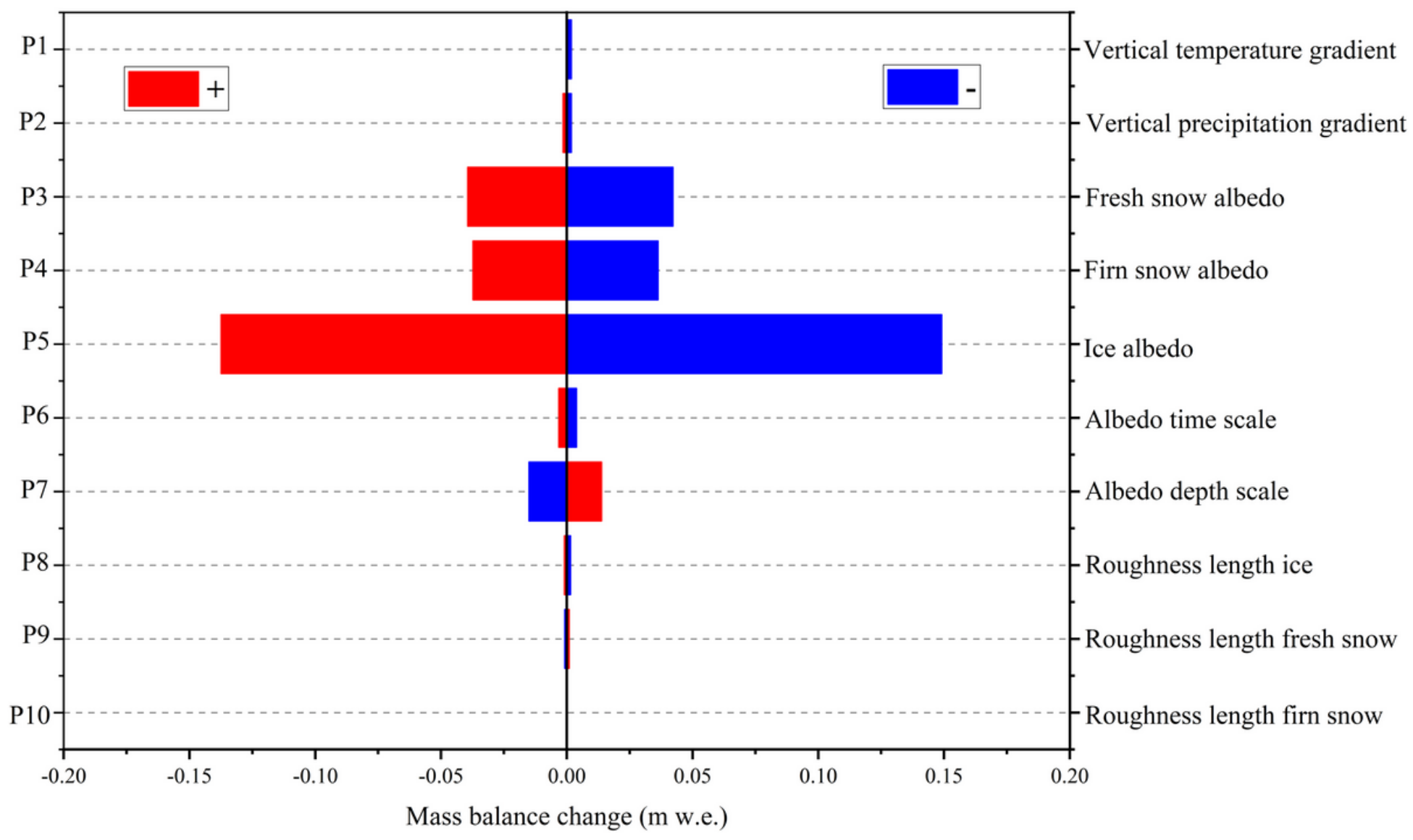

Figure 9

Parameter sensitivity assessment on the Urumqi Glacier No.1 in COSIMA. 


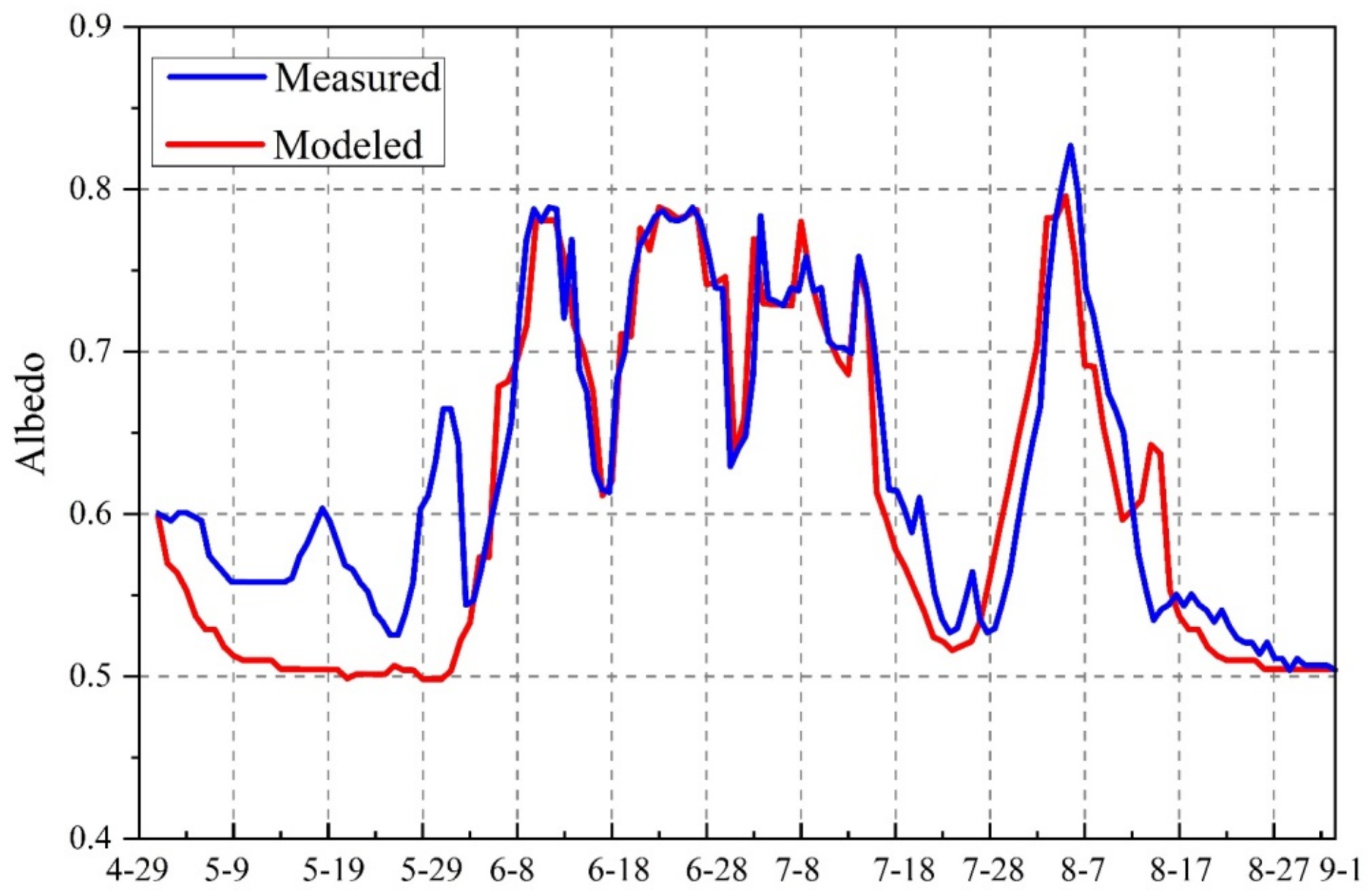

Figure 10

Measured and modeled albedo on Urumqi Glacier No.1 during ablation period 2018. In COSIMA the following optimized values have been chosen: albedo fresh snow $=0.83$, albedo firn snow $=0.58$, albedo ice $=0.35$, albedo time scale $=1.1$ day and albedo depth scale $=3 \mathrm{~cm}$ (see Table 2 ). 

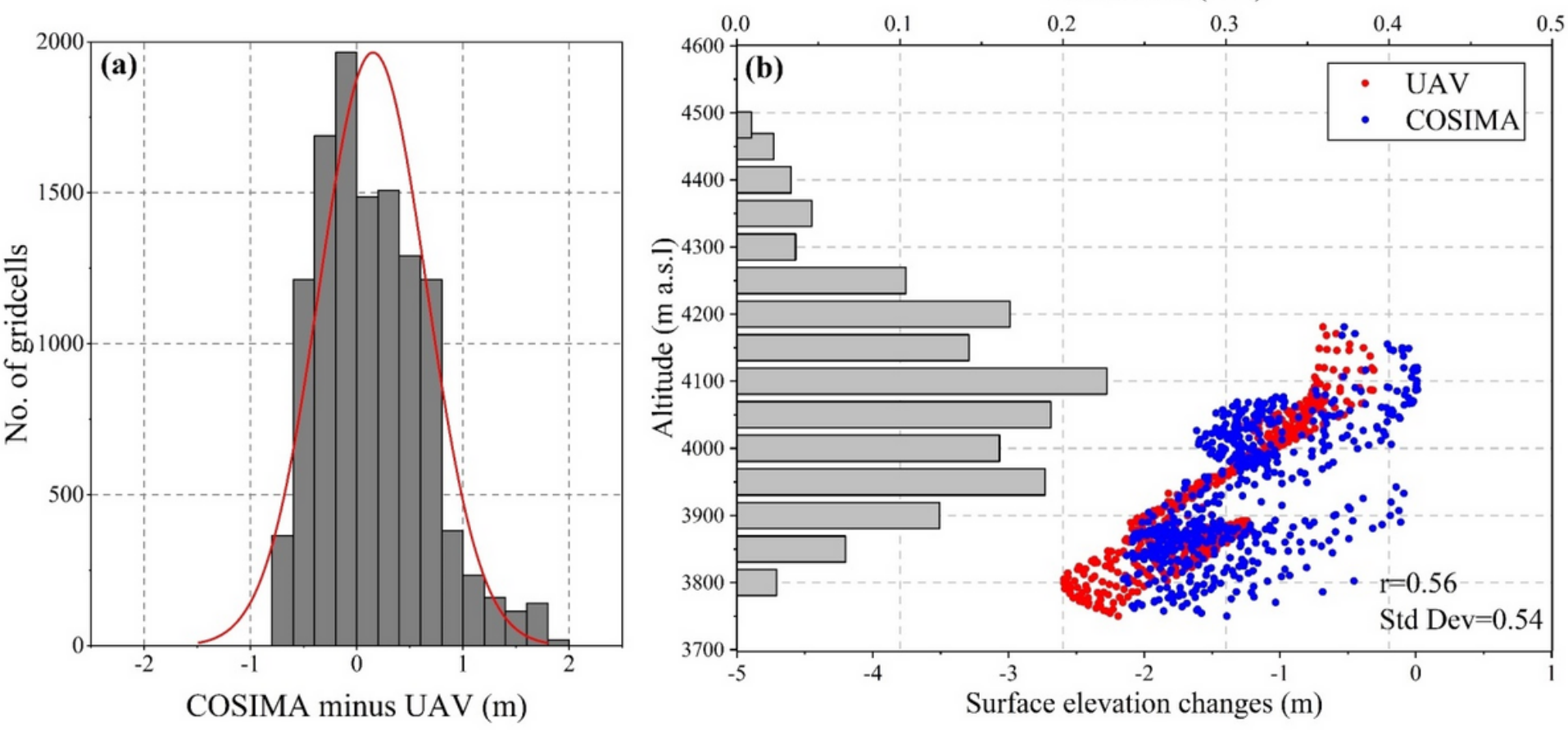

Figure 11

Histogram of differences of the surface elevation changes of Urumqi Glacier No.1 estimated from COSIMA and from Wang et al. (2021) by means of two high-resolution UAV surveys for the ablation period 2018 (a). Profiles of differences between surface elevation changes based on COSIMA result and the repeated UAV surveys from Wang et al. (2021) (b). Differences are averaged over $100 \mathrm{~m}$ altitude bins. 


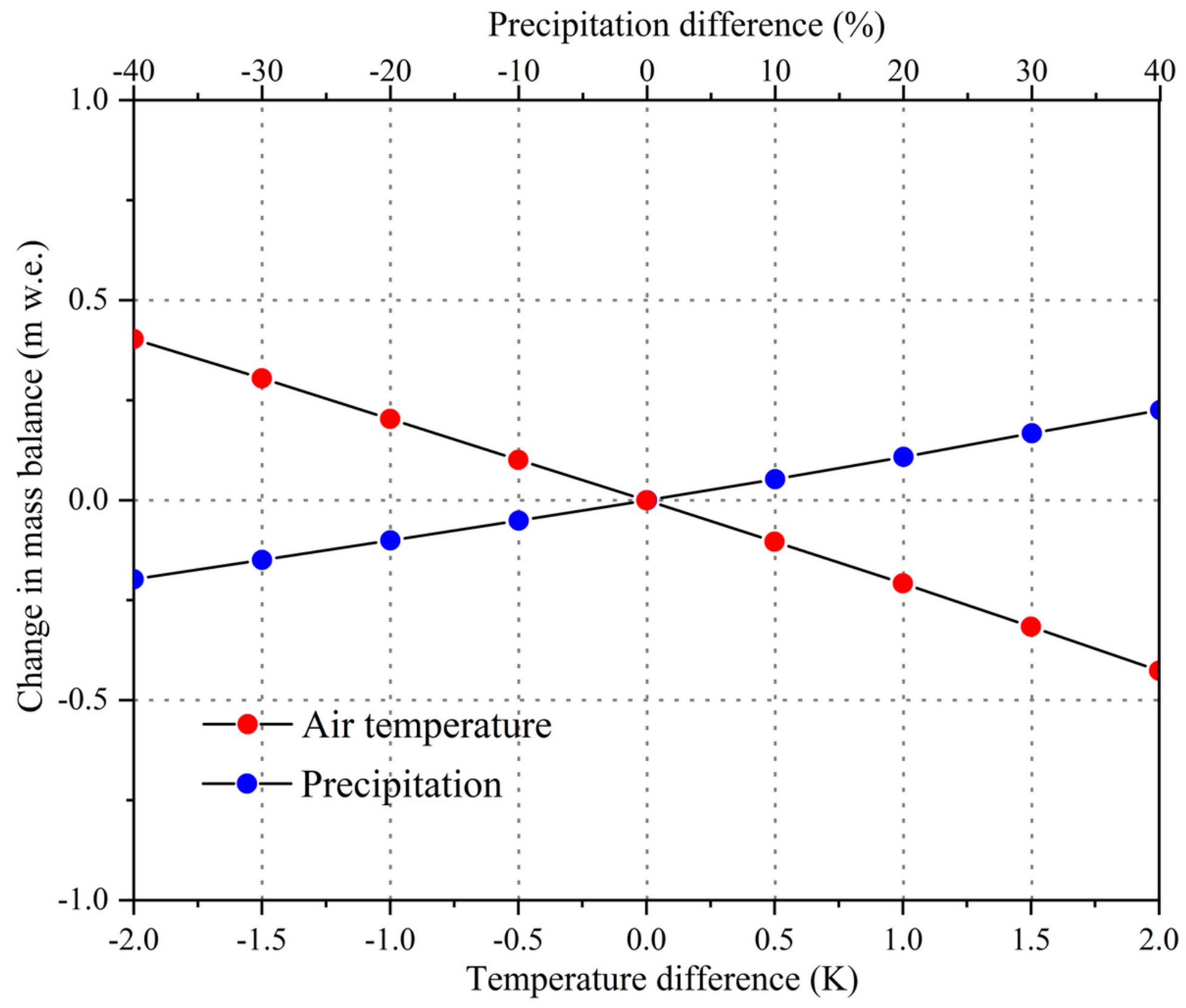

Figure 12

Mass balance sensitivity by perturbing mean air temperature at a step of $0.5 \mathrm{~K}$ and precipitation at percentage intervals of $10 \%$. 


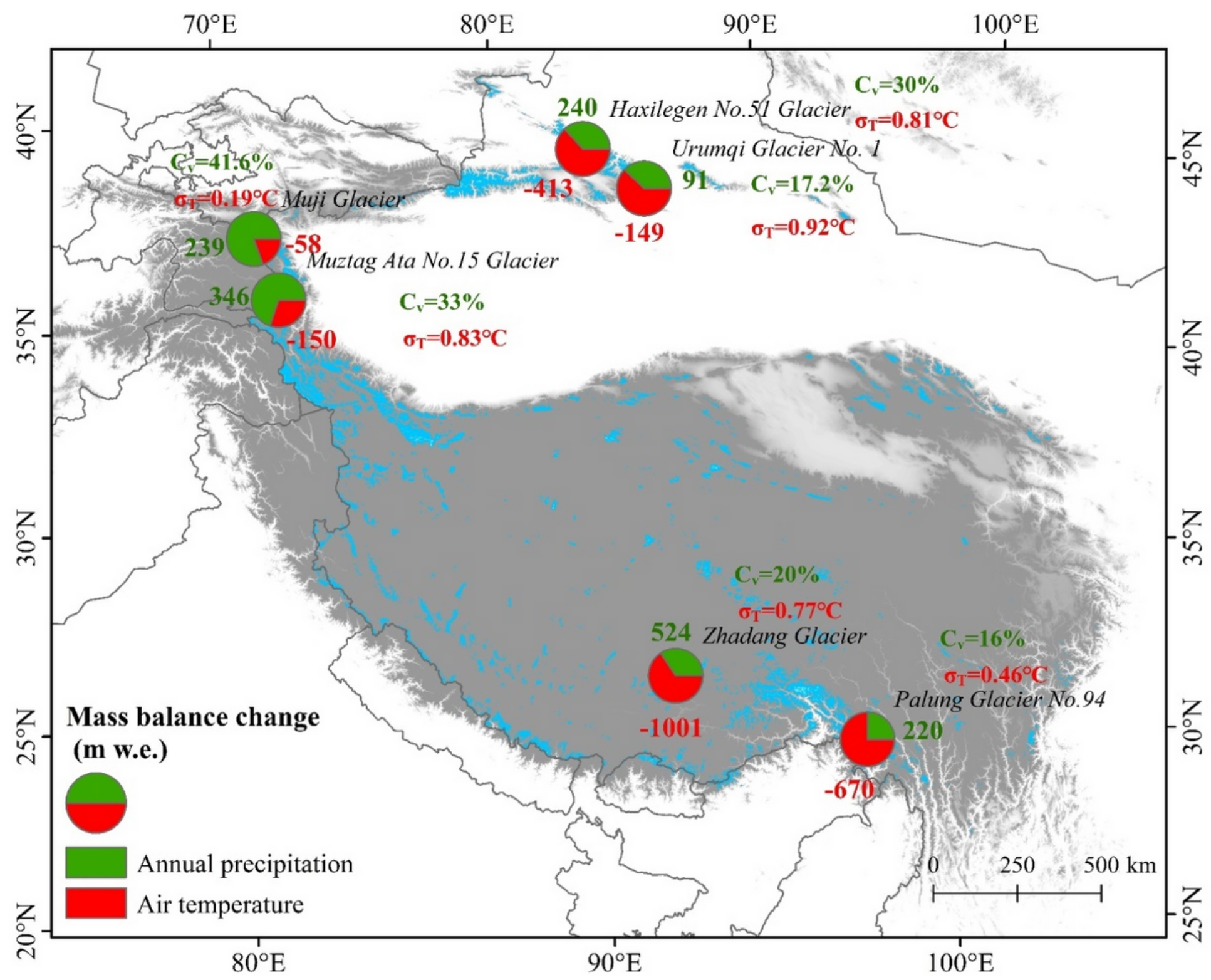

Figure 13

The spatial pattern of mass balance change of Urumqi Glacier No. 1 with other glaciers in western China when ablation period air temperature or annual precipitation is changed by the interannual variability in ablation period air temperature $(\sigma \mathrm{T})$ or annual precipitation $(\mathrm{Cv})$ at Chinese national meteorological stations near the glaciers. Note that mass balance changes are derived using data from Yang et al. (2013), Zhu et al.( 2017), Zhang et al. (2018), Zhu et al. (2018) and Zhu et al. (2020), respectively. The red circles with olive green portion show mass balance changes corresponding with different interannual variabilities. Glaciers are shown in light blue, and the background is the Global Multi-resolution Terrain Elevation Data (GMTED2010) dataset sourced from the USGS (http://topotools.cr.usgs.gov/GMTED_viewer/viewer.htm). 


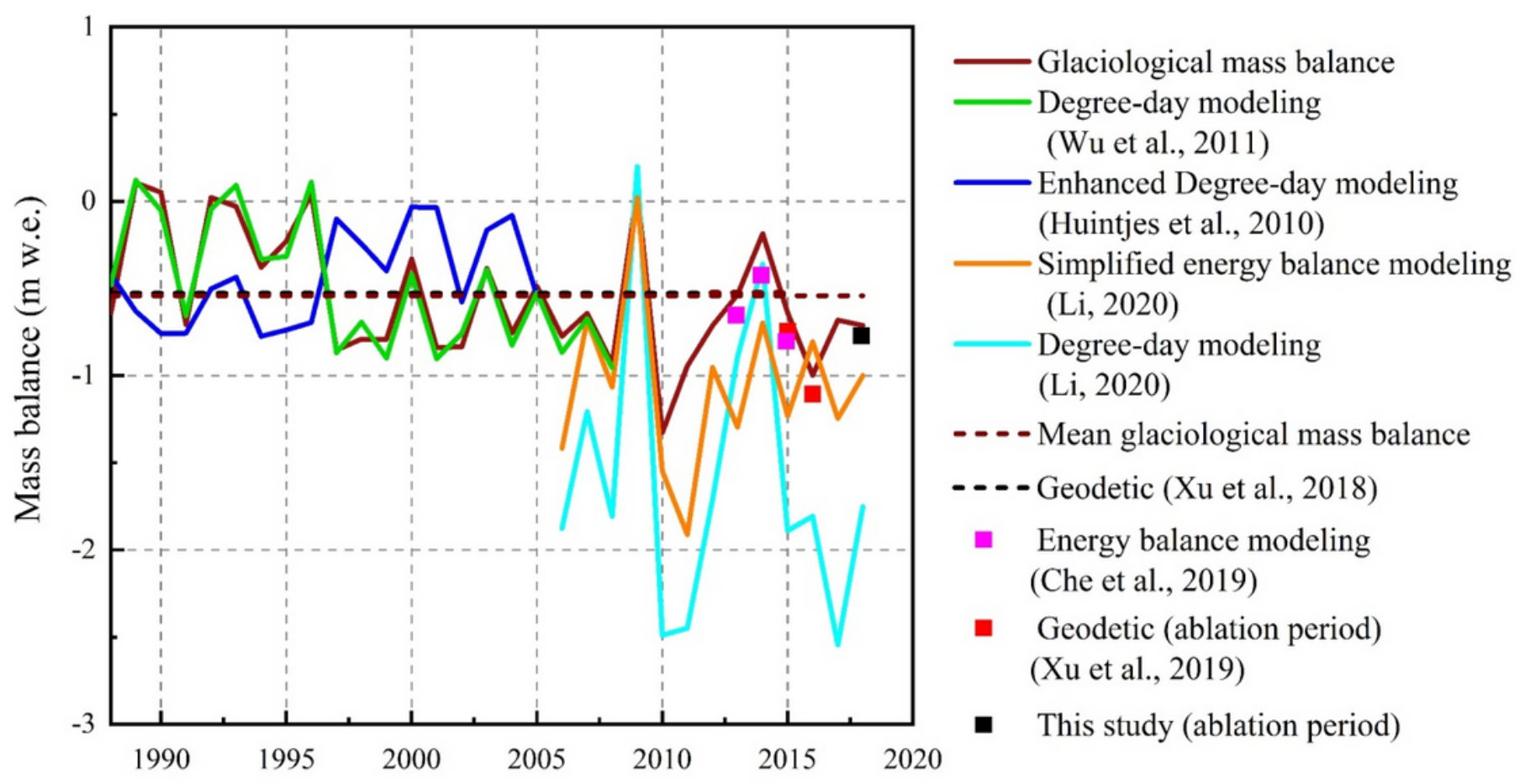

Figure 14

Mass balance estimates of Urumqi Glacier No. 1 from different studies and methods.

\section{Supplementary Files}

This is a list of supplementary files associated with this preprint. Click to download.

- AppendixAB.docx 